Article

\title{
Insight into the Influence of Properties of Poly(Ethylene-co-octene) with Different Chain Structures on Their Cell Morphology and Dimensional Stability Foamed by Supercritical $\mathrm{CO}_{2}$
}

\author{
Dongyang Li ${ }^{1} \mathbb{D}$, Yichong Chen ${ }^{1}$, Shun Yao ${ }^{1}$, Hong Zhang ${ }^{1}$, Dongdong Hu ${ }^{1,2}$ and Ling Zhao ${ }^{1,3, *}$ \\ 1 State Key Laboratory of Chemical Engineering, East China University of Science and Technology, \\ Shanghai 200237, China; lidongyang19960327@163.com (D.L.); cccyccxc@163.com (Y.C.); \\ yaoshun0727@163.com (S.Y.); zhanghong365@163.com (H.Z.); hudd@ecust.edu.cn (D.H.) \\ 2 Shanghai Key Laboratory of Multiphase Materials Chemical Engineering, \\ East China University of Science and Technology, Shanghai 200237, China \\ 3 College of Chemical Engineering, Xinjiang University, Urumqi 830046, China \\ * Correspondence: zhaoling@ecust.edu.cn; Tel.: +86-21-64253175; Fax: +86-21-64253528
}

\section{check for}

updates

Citation: Li, D.; Chen, Y.; Yao, S.; Zhang, H.; Hu, D.; Zhao, L. Insight into the Influence of Properties of Poly(Ethylene-co-octene) with Different Chain Structures on Their Cell Morphology and Dimensional Stability Foamed by Supercritical $\mathrm{CO}_{2}$. Polymers 2021, 13, 1494. https://doi.org/10.3390/ polym13091494

Academic Editor: José Ignacio Velasco

Received: 8 April 2021

Accepted: 1 May 2021

Published: 6 May 2021

Publisher's Note: MDPI stays neutral with regard to jurisdictional claims in published maps and institutional affiliations.

Copyright: (c) 2021 by the authors. Licensee MDPI, Basel, Switzerland. This article is an open access article distributed under the terms and conditions of the Creative Commons Attribution (CC BY) license (https:/ / creativecommons.org/licenses/by/ $4.0 /)$.
Abstract: Poly(ethylene-co-octene) (POE) elastomers with different copolymer compositions and molecular weight exhibit quite distinctive foaming behaviors and dimensional stability using supercritical carbon dioxide $\left(\mathrm{CO}_{2}\right)$ as a blowing agent. As the octene content decreases from $16.54 \%$ to $4.48 \%$ with constant melting index of 1 , both the melting point and crystallinity of POE increase, due to the increase in fraction of ethylene homo-polymerization segment. the foaming window of POE moves to a narrow higher temperature zone from $20-50{ }^{\circ} \mathrm{C}$ to $90-110{ }^{\circ} \mathrm{C}$ under $11 \mathrm{Mpa} \mathrm{CO}_{2}$ pressure, and $\mathrm{CO}_{2}$ solubility as well as $\mathrm{CO}_{2}$ desorption rate decrease, so that the average cell diameter becomes larger. POE foams with higher octene content have more serious shrinkage problem due to lower compression modulus, weaker crystal structure and higher $\mathrm{CO}_{2}$ permeability. As POE molecular weight increases at similar octene content, there is little effect on crystallization and $\mathrm{CO}_{2}$ diffusion behavior, the foaming window becomes wider and cell density increases, mainly owing to higher polymer melt strength, the volume shrinkage ratio of their foams is less than $20 \%$ because of similar higher polymer modulus. In addition, when the initiate expansion ratio is over 17 times, POE foams with longer and thinner cell wall structures are more prone to shrinkage and recovery during aging process, due to more bending deformation and less compression deformation.

Keywords: poly(ethylene-co-octene); supercritical carbon dioxide; foaming behavior; shrinkage behavior; crystallization; $\mathrm{CO}_{2}$ solubility

\section{Introduction}

POE has easy processing, good chemical stability, good aging recyclability, and acoustic insulation performance [1-4], and POE foams are mainly used as cushioning and sealing materials. POE can be foamed by either chemical blowing agents [5-7] or physical blowing agents [8]. Using azodicarbonamide (ADC) as chemical blowing agent, Nayak N.C. and Tripathy, D.K prepared microcellular POE with uniform closed cell distribution by the help of silica filler loading, Tatibouet et al. [6] applied injection molding to prepare low-density POE foams with different crosslinking degrees and molecular weights. Supercritical $\mathrm{CO}_{2}$ and nitrogen $\left(\mathrm{N}_{2}\right)$ are environmentally friendly and cheap physical foaming agents, especially supercritical $\mathrm{CO}_{2}$ has higher solubility and shorter saturation time than supercritical $\mathrm{N}_{2}$ under same saturation pressure, which can effectively reduce foam density and improve process efficiency. Zhai et al. [8] used batch foaming process to prepare microcellular POE foams blown by supercritical $\mathrm{CO}_{2}$, and found that the increase of POE molecular weight can significantly inhibit the coalescence of bubble and increase cell density during bubble growth, due to increased melt strength. The addition of multiwall carbon nanotube in POE also can improve polymer blend strain hardening to protect cell wall from destruction [9]. 
Most common POE is a random copolymer, which can be produced by Dow Chemical with constrained geometry catalyst technology [10]. Similar to other thermoplastic elastomers (TPEs), POEs usually are composed of two types of segments: soft amorphous segment and hard crystalline segment [11]. Crystalline segment usually governs the tensile strength, while the segments with more octene content provide elastic characteristics. Bensason et al. [10] found that the increase in octene content led to lower density and crystallinity of POE. If the density was less than $890 \mathrm{~kg} / \mathrm{m}^{3}$, corresponding to $25 \%$ crystallinity, the lamellae crystals disappeared, and polymers had pure fringed micellar or bundled crystals, and the tensile behavior changed from typical necking to uniform elastomer characteristics stretch. However, there are few studies about the influence of POEs with different soft segment content on their foaming behavior. Yeh et al. [12] studied the effect of hard segment content and soft segment type on the properties and foaming behaviors of thermoplastic polyurethane (TPU) composed of hard segments $\left(4,4^{\prime}\right.$-methylenebis (phenyl isocyanate) and soft segments. $\mathrm{CO}_{2}$ was mainly dissolved in soft segments, the increase of hard segment content could increase its crystallinity. The TPUs foams with higher hard segment content had smaller cell size and higher cell density, due to heterogeneous nucleation. The TPUs with different soft segment type (polytetramethylene ether glycol, 1,4-butanediol or poly (1,4-butylene adipate) had different foaming behaviors and cell morphology. Jiang et al. [13] carried out the solid-state foaming process of polyether ester elastomer composed of poly(tetra methylene glycol) (PTMG) "soft" blocks and poly(butylene terephthalate) (PBT) "hard" blocks, it was found that the solubility and diffusivity of $\mathrm{CO}_{2}$ in PTMG segments is significantly higher than in PBT segments. With higher hard segment content, the foaming temperature window becomes narrow and shifts to a higher temperature range, and foamed samples had smaller cell size, higher cell density and lower expansion ratio. Many new foaming technologies that use supercritical fluid as a blowing agent to produce TPEs foams have been developed, such as autoclave bead foaming, extrusion foaming, microcellular injection molding, and compression molding foaming processes [14]. Supercritical $\mathrm{CO}_{2}$ foaming technologies has been commercialized successfully to manufacture TPU elastomer microcellular foams with excellent rebounding ability for sports shoe materials [15]; supercritical fluid foaming technologies show good commercial potential in the green production of POE microcellular foams.

Shrinkage is the most common problem for elastomer foaming. During the aging stage after foaming, the residual $\mathrm{CO}_{2}$ in cell will diffuse out of polymer foam, and air will diffuse into cells. Generally, the permeability of $\mathrm{CO}_{2}$ in the polymer is one order of magnitude higher than that of air, which will create a negative pressure inside the cells. The elastomer is in a rubbery state at room temperature and has a low modulus, so that its cells are difficult to resist this negative pressure and the shrinkage will happen. It has found the linear shrinkage degree of TPU foam can reach 17-19\% [16]. Lan et al. [17] found that chain segment's relaxation and hydrogen bonding among TPU molecular chains play significant roles in cell stabilization. Some works have been done on the anti-shrinkage problem of elastomer foams. Zhang et al. [18] added a small amount of acrylonitrilebutadiene-styrene copolymer (ABS) to TPU for reactive blending with the assistance of maleic anhydride and dicumyl peroxide, they found that the TPU/ABS blend foams had not only higher expansion ratios, but also lower volume shrinkage ratio because of the increasing modulus. Generally, the shrinkage of polymer foam is determined by mechanical properties of polymer matrix, expansion ratio and cell morphology, and different kind of blowing agents [19-21]. Since the difference in octene content and molecular weight for POE could significantly affect polymer crystallization and mechanical properties as well as cell morphology [8,10], POE foams with different chain structures blown with $\mathrm{CO}_{2}$ should exhibit different shrinking behavior, which also has not been reported until now.

In this study, commercial POEs with same melting index (MI) but different octene content, or with the same octene content but different molecular weight and melting index, were chosen. The effect of their rheological, melting and crystallization, mechanical properties as well as $\mathrm{CO}_{2}$ solubility on cell morphology were systematically investigated, 
and the shrinking behavior of these POE foams also was analyzed based on the difference between $\mathrm{CO}_{2}$ and air permeability in polymers, polymer mechanical properties, and cell wall structural parameters. The results can give an insight to understand POE foaming and aging behavior blown by supercritical $\mathrm{CO}_{2}$.

\section{Experimental}

\subsection{Materials and Foam Preparations}

Five commercial POEs with different octene content and molecular weight produced by Dow Chemical Company (Midland, MI, USA) were selected, shown in Table $1 . \mathrm{CO}_{2}$ (purity: $99.99 \mathrm{wt} \%$ ) was purchased from Air Liquide Co., Ltd. (Shanghai, China).

Table 1. Characteristics of the selected POEs.

\begin{tabular}{cccccc}
\hline Sample Number & Density $\left(\mathbf{g} / \mathbf{c m}^{\mathbf{3}}\right)$ & $\mathbf{M}_{\mathbf{w}}(\mathbf{g} / \mathbf{m o l})$ & $\mathbf{M}_{\mathbf{n}} \mathbf{( g / \mathbf { m o l } )}$ & $\mathbf{M}_{\mathbf{w}} / \mathbf{M}_{\mathbf{n}}$ & $\mathbf{M e l t i n g} \mathbf{I n d e x}$ \\
\hline POE1 & 0.857 & 110,268 & 41,508 & 2.66 & 1 \\
POE2 & 0.885 & 78,669 & 33,719 & 2.33 & 1 \\
POE3 & 0.902 & 89,888 & 33,458 & 2.69 & 1 \\
POE4 & 0.902 & 81,983 & 30,357 & 2.70 & 3 \\
POE5 & 0.902 & 68,618 & 26,928 & 2.55 & 4.3 \\
\hline
\end{tabular}

\subsubsection{Batch Foaming Process}

The foaming experiment was carried out in a batch high pressure vessel of $60 \mathrm{~mL}$ by fast depressurization method. Considering preliminary experiments and previous works [8], the saturation pressure was selected as $11 \mathrm{MPa}$, the POE sheets $(10 \mathrm{~mm}$ diameter $\times 2 \mathrm{~mm}$ thickness) was saturated $1 \mathrm{~h}$ with supercritical $\mathrm{CO}_{2}$ at certain temperature to reach equilibrium. After a fast depressurization step with a maximum depressurization rate of $350 \mathrm{MPa} / \mathrm{s}$, the high-pressure vessel was cooled and the foamed sample was taken out to study its shrinking behavior.

\subsubsection{Shrinking Process of POE Foam Sample}

The foamed POE sample was taken out from high pressure vessel within $1 \mathrm{~min}$ and its density was measured, then this sample was kept in the atmosphere, and its density was repeatedly measured at a certain time interval until the foam density did not change.

\subsection{3. $\mathrm{CO}_{2}$ Desorption Process}

Solubility and diffusivity can usually be determined by two methods: sorption [22] and desorption [23]. The desorption method was used to study the solubility and permeability of $\mathrm{CO}_{2}$ in POE. The saturation process was carried out in the vessel, maintaining a certain temperature and pressure. After saturation, the vessel was put in cold water to cool for $4 \mathrm{~min}$, and then, the pressure was released within $1 \mathrm{~min}$. POE sheets were taken out and put in the balance, and the weight of the POE sample on the balance was recorded at $25^{\circ} \mathrm{C}$ atmospheric pressure over time. The solubility and diffusion coefficients of $\mathrm{CO}_{2}$ in $\mathrm{POE}$ could be obtained by fitting desorption curves and extrapolating to zero with Equation (1).

$$
\frac{M_{t}}{M_{o}}=1-\frac{4}{d}\left(\frac{D t}{\pi}\right)^{1 / 2}
$$

where $M_{t}$ is the mass uptake at any time $t, M_{o}$ is the equilibrium mass uptake (or $\mathrm{CO}_{2}$ solubility), $d$ is the POE sample thickness, and $D$ is the desorption diffusion coefficient.

\subsection{Characterizations}

\subsection{1. ${ }^{13} \mathrm{C}$ NMR Procedures}

Copolymer composition distribution was measured by ${ }^{13} \mathrm{C}$ NMR spectra, the carbon assignments and composition calculation were performed according to ASTM D5017-96 
method [24]. POE samples were dissolved in deuterated o-dichlorobenzene at $150{ }^{\circ} \mathrm{C}$. Then, the solutions were scanned at $110{ }^{\circ} \mathrm{C}$ by AVANCE NEO $700 \mathrm{MHz}$ (Karlsruhe, Germany) with $90^{\circ}$ pulse angle, and the pulse was set as zgig30.

\subsubsection{Differential Scanning Calorimetry (DSC) Analysis}

DSC (NETZSCH DSC 204PH, Selb, Germany) equipped with high pressure attachment was employed to measure the melting and crystallization behaviors of POE samples in atmospheric $\mathrm{N}_{2}$ pressure and $11 \mathrm{MPa} \mathrm{CO}_{2}$. Firstly, gas replacement and pressurization were performed, and samples were saturated for $1 \mathrm{~h}$, then all samples were heated to $150{ }^{\circ} \mathrm{C}$ at first and then cooled to $30^{\circ} \mathrm{C}$ with the rate of $10^{\circ} \mathrm{C} / \mathrm{min}$. The melting temperature $\left(\mathrm{T}_{\mathrm{m}}\right)$ and crystallization temperature $\left(\mathrm{T}_{\mathrm{c}}\right)$ were determined.

\subsubsection{Wide-Angle-X-ray Diffraction (WAXD) Analysis}

The structural change among POE samples were recorded by X-Ray Polycrystalline Diffractometer (D8 Advance, Karlsruhe, Germany) with $\mathrm{Cu}$ radiation at room temperature. The diffraction scans were collected in the range of $2 \theta$ values from 4 to 60 degrees, controlling a sampling rate of $1 \mathrm{~Hz}$.

\subsubsection{Rheological Properties Measurement}

The dynamic shear rheological behavior of POE was measured by a rheometer (HAAKE MARS III, Waltham, MA, USA) with $20 \mathrm{~mm}$ parallel-plate geometry. In the linear viscoelastic zone (a controlled deformation of 1.5\%), dynamic oscillate tests were operated by adjusting angular frequency $\omega(100$ to $0.1 \mathrm{rad} / \mathrm{s})$, or temperature (from 30 to $\left.200{ }^{\circ} \mathrm{C}\right)$, under a nitrogen atmosphere. The elongational rheological tests were also carried out by HAAKE MARS III at $150{ }^{\circ} \mathrm{C}$ with the rectangular samples $(10 \mathrm{~mm}$ wide, $20 \mathrm{~mm}$ long, and $1 \mathrm{~mm}$ thick). Strain rates of $0.05,0.1,0.2$, and $0.3 \mathrm{~s}^{-1}$ were set in the elongational rheological tests.

\subsubsection{Mechanical Property Measurement}

3300 series dual column desktop electronic universal tester (Instron 3367, Shanghai, China) was used to perform compression tests. A cylindrical sample with a diameter of $30 \mathrm{~mm}$ and height of $10 \mathrm{~mm}$ was loaded between two flat-surface stages and the strain ramp rate was $1.0 \mathrm{~mm} / \mathrm{min}$.

\subsubsection{Thermo-Mechanical Property Measurement}

Dynamic mechanical analysis (DMA) (TA850, New Castle DE, USA) was used to measure the creep behavior of POEs. All creep tests were carried out at a fixed level of $0.75 \mathrm{MPa}$ and $40{ }^{\circ} \mathrm{C}$ for $60 \mathrm{~min}$. Then the POE samples were recovered for $40 \mathrm{~min}$ after the stress was removed.

\subsubsection{Foam Characterization}

The foamed samples were tested by the density module provided by METTLER TOLEDO, according to the test standard was ASTM D792-00. The volume expansion ratio, $R_{v}$, is determined by Equation (2)

$$
R_{v}=\rho_{0} / \rho_{f}
$$

where $\rho_{f}$ is the density of POE foam and $\rho_{0}$ is the density of POE polymer.

The cell morphology analysis of POE foams was realized by a scanning electron microscope (Nova Nano SEM 450). The foam samples were freeze-fractured in liquid nitrogen and the fracture surface was sputter-coated with platinum for SEM observation. 
The cell density $N_{o}$ is the number of cells per cubic centimeter of solid polymer, which is determined from Equation (3)

$$
N_{o}=\left[\frac{n M^{2}}{A}\right]^{3 / 2} R_{v}
$$

where $n$ is the number of cells in the SEM micrograph, $M$ is the magnification factor, $A$ is the area of the micrograph $\left(\mathrm{cm}^{2}\right)$.

Cell wall thickness $h$ is determined by Equation (4):

$$
h=\left(\frac{1}{\sqrt[3]{1-1 / R_{v}}}-1\right) \times l_{0}
$$

where $l_{0}$ is the cell length in the initial state.

\subsubsection{Air Permeability in POEs}

Air permeability in POE was determined in labthink air permeability tester (BTY-B2P, Jinan, China). The pressure difference on both sides of the film was kept at $0.1 \mathrm{MPa}$. The permeability coefficient of air was calculated by Equation (5).

$$
J=\frac{P e \times \Delta p}{L}
$$

$\mathrm{Pe}$ is the permeability; $\Delta p$ is the pressure difference; $L$ is the film thickness; $J$ is the volume flux through the film.

\section{Results and Discussion}

\subsection{Crystallization and Melting Behavior of Different POEs}

Generally, the temperature range for $\mathrm{CO}_{2}$ foaming polymer is close to its melting range, the melting behavior of $\mathrm{POE}$ is affected by its crystalline structure and $\mathrm{CO}_{2}$ plasticization Figure 1 showed the diffraction patterns of different POEs measured by WAXD at room temperature. There were four peaks $2 \theta=19.8^{\circ}, 2 \theta=21.4,2 \theta=23.5$, and $2 \theta=36.1$, which were very similar to the results [11] of Perez. Russell et al. [25] believed that the peak at $2 \theta=19.8^{\circ}$ represented the influence of 1-octene branches in the crystal structure. Figure 2 showed the ${ }^{13} \mathrm{C}-\mathrm{NMR}$ spectrum and Table 2 summarized the triad sequence length distribution of selected POE samples. There were a lot of ethylene homo-polymerization sections (EEE) but almost no octene homo-polymerization sections (OOO) in POE1-5. The addition of octene destroyed the crystalline structure of polyethylene. As octene content increase for POE1-3, the fractions of EEO + OEE, EOE, OEE, EOO + OOE and OEO increase, and the peaks at $2 \theta=21.4,2 \theta=23.5$ and $2 \theta=36.1$ all decreased significantly in Figure 1a. This phenomenon was also corresponded to the work [10] of Bensason, S, POE1 only had $2 \theta=19.8^{\circ}$ peaks, proving that POE1 contained a single bundled crystals, and other samples had both bundled crystals and lamellar crystals. However, POE3-5 with similar octene content had similar triad sequence length distribution, so that they have similar peak position and peak intensity in the spectrum in Figure 1b, indicating that the molecular weight of POEs has less effect on their crystal form and crystallinity.

Table 2. Triad sequence length distribution of POEs by ${ }^{13} \mathrm{C}-\mathrm{NMR}$ spectrum.

\begin{tabular}{cccccccc}
\hline Sample & Octene Content (\%) & EEE (\%) & EEO + OEE (\%) & OEO (\%) & EOE (\%) & EOO + OOE (\%) & OOO (\%) \\
\hline POE1 & 16.54 & 60.91 & 22.12 & 1.45 & 11.69 & 3.54 & 0.41 \\
POE2 & 8.34 & 73.82 & 15.83 & 0.61 & 7.91 & 0.98 & 0 \\
POE3 & 4.48 & 86.13 & 9.42 & 0 & 4.09 & 0.39 & 0.72 \\
POE4 & 4.89 & 84.91 & 10.15 & 0.48 & 3.73 & 0 \\
POE5 & 4.92 & 83.81 & 10.71 & 0.52 & 4.36 & 0.33 & 0 \\
\hline
\end{tabular}



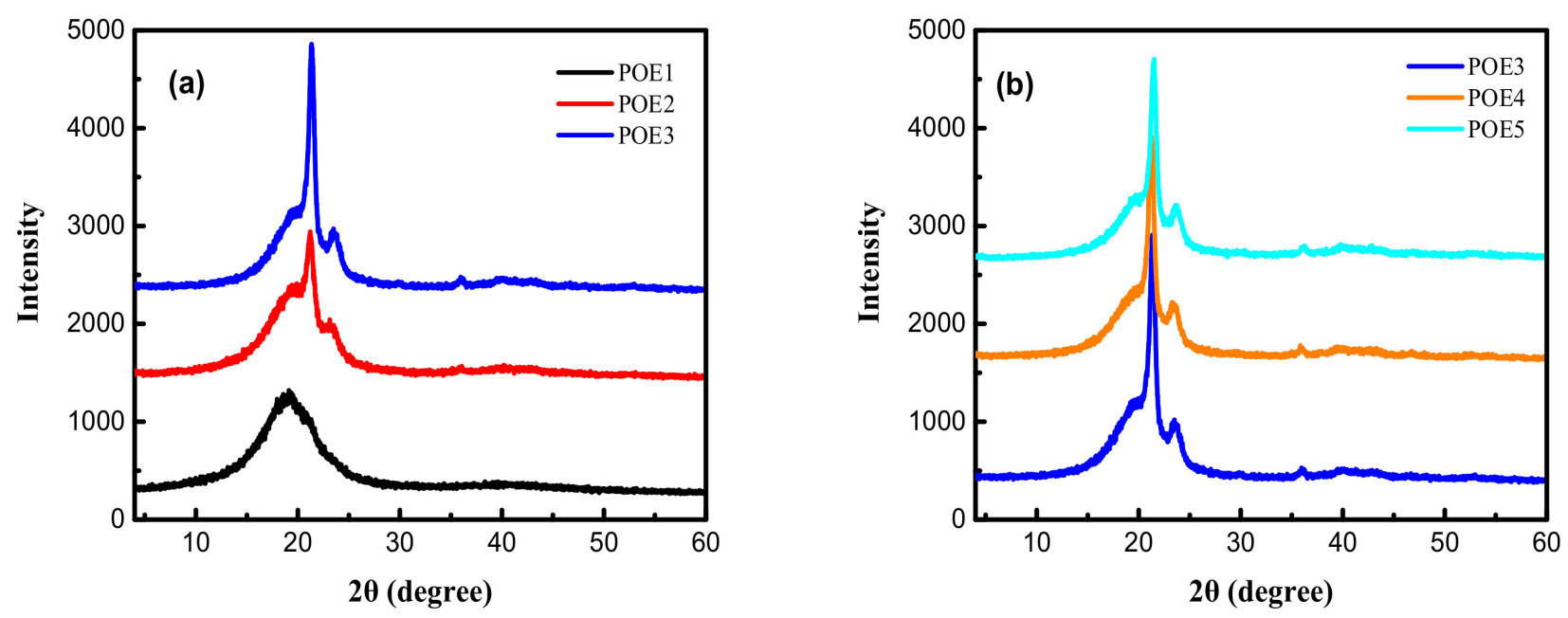

Figure 1. X-ray diffractograms of different samples at room temperature. (a) POE samples with same Melting Index (MI); (b) POE samples with same octene content.

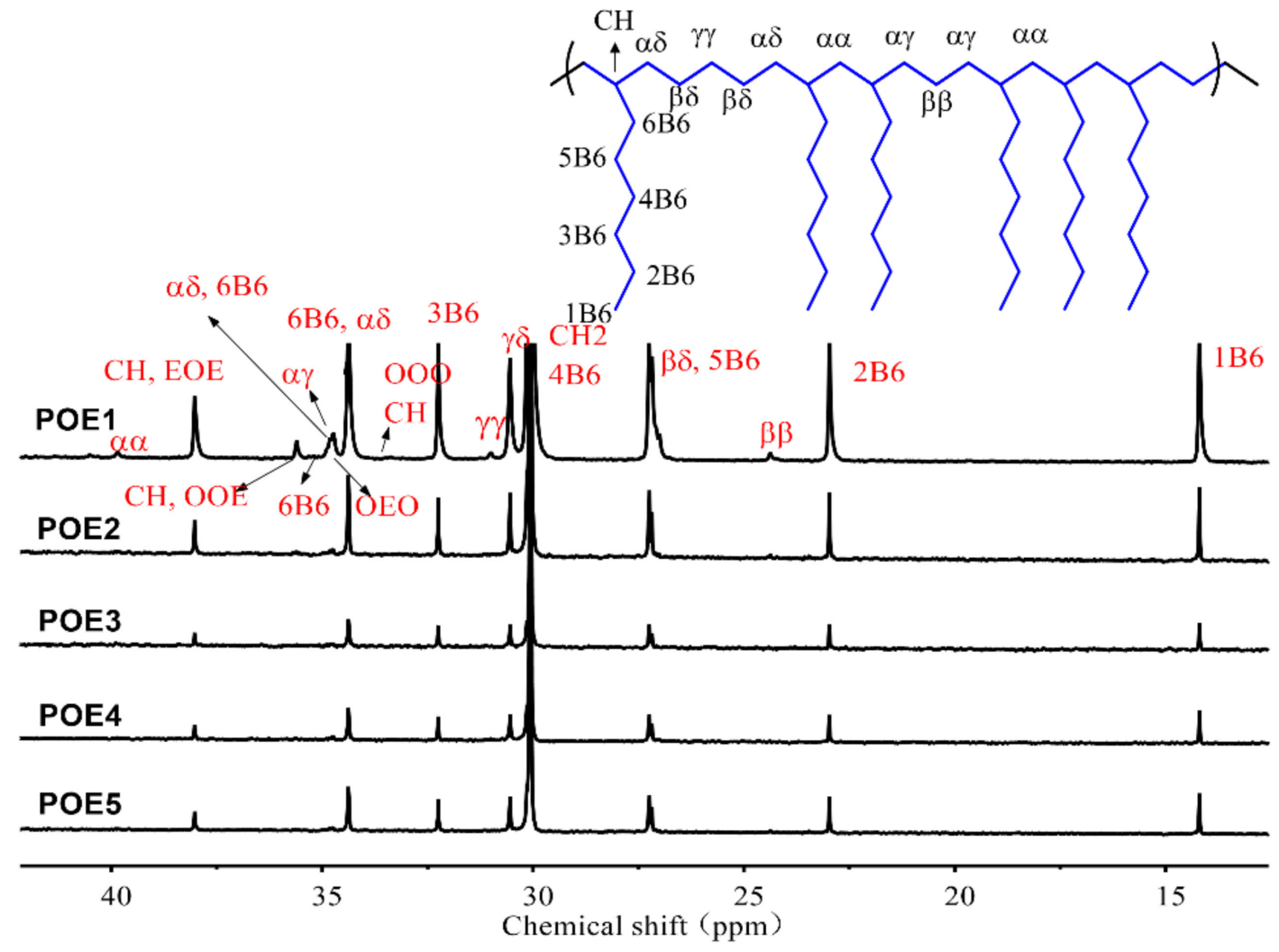

Figure $2 .{ }^{13} \mathrm{C}-\mathrm{NMR}$ spectrum for poly(ethylene-co-octene) (POE) samples.

DSC test results were shown in Table 3, Figures 3 and 4. The decrease in octene content or increase in molecular weight would lead to an increase of POE crystallinity. The dissolved $\mathrm{CO}_{2}$ causes POE to be swollen and leads to an increase in free volume and chain mobility, which makes crystallization and melting temperature of POE samples shift to lower temperature values. The strong $\mathrm{CO}_{2}$ plasticization effect can significantly reduce the crystallinity of POE samples. High pressure $\mathrm{CO}_{2}$ plasticization is mainly manifested in two aspects of dissolved gas and static pressure [26]. Figure 5 summarized the solubility properties of $\mathrm{CO}_{2}$ in different $\mathrm{POE}$ samples at room temperature $\left(\mathrm{T}=25^{\circ} \mathrm{C}\right)$ and $11 \mathrm{MPa}$ after $\mathrm{CO}_{2}$ saturated for $15 \mathrm{~h}$. As expected, the increase in octene content significantly increases the solubility of $\mathrm{CO}_{2}$ in polymer, due to lower crystallinity and larger free volume. 
It is worth noting that although POE with higher octene content has higher $\mathrm{CO}_{2}$ solubility, the melting temperature of POE with lower octene content decreases more significantly shown in Figure 4. As the content of octene increases, the effect of static pressure becomes stronger, which reduces the free volume of the matrix and hinder the POE chain mobility.

Table 3. Thermophysical properties of POE measured by DSC cooling curves.

\begin{tabular}{ccccccc}
\hline \multirow{2}{*}{ Sample } & \multicolumn{9}{c}{$\mathbf{0 . 1} \mathbf{~ M P a ~ \mathbf { N } _ { \mathbf { 2 } }}$} & \multicolumn{2}{c}{$\mathbf{1 1} \mathbf{M P a}_{\mathbf{C O}}$} \\
\cline { 2 - 7 } & $\mathbf{T}_{\mathbf{c}}\left({ }^{\circ} \mathbf{C}\right)$ & $\mathbf{T}_{\mathbf{m}}\left({ }^{\circ} \mathbf{C}\right)$ & $\mathbf{X}_{\mathbf{c}} \mathbf{( \% )}$ & $\mathbf{T}_{\mathbf{c}}\left({ }^{\circ} \mathbf{C}\right)$ & $\mathbf{T}_{\mathbf{m}}\left({ }^{\circ} \mathbf{C}\right)$ & $\mathbf{X}_{\mathbf{c}} \mathbf{( \% )}$ \\
\hline POE1 & - & 49.3 & - & - & 48.1 & - \\
POE2 & 59.1 & 78.5 & 8.2 & 57.6 & 74.5 & 1.1 \\
POE3 & 80.5 & 102.4 & 15.1 & 75.5 & 97.7 & 9.2 \\
POE4 & 77.7 & 102.2 & 14.8 & 74.1 & 96.8 & 8.4 \\
POE5 & 77.5 & 102.1 & 14.7 & 73.5 & 96.5 & 8.1 \\
\hline
\end{tabular}
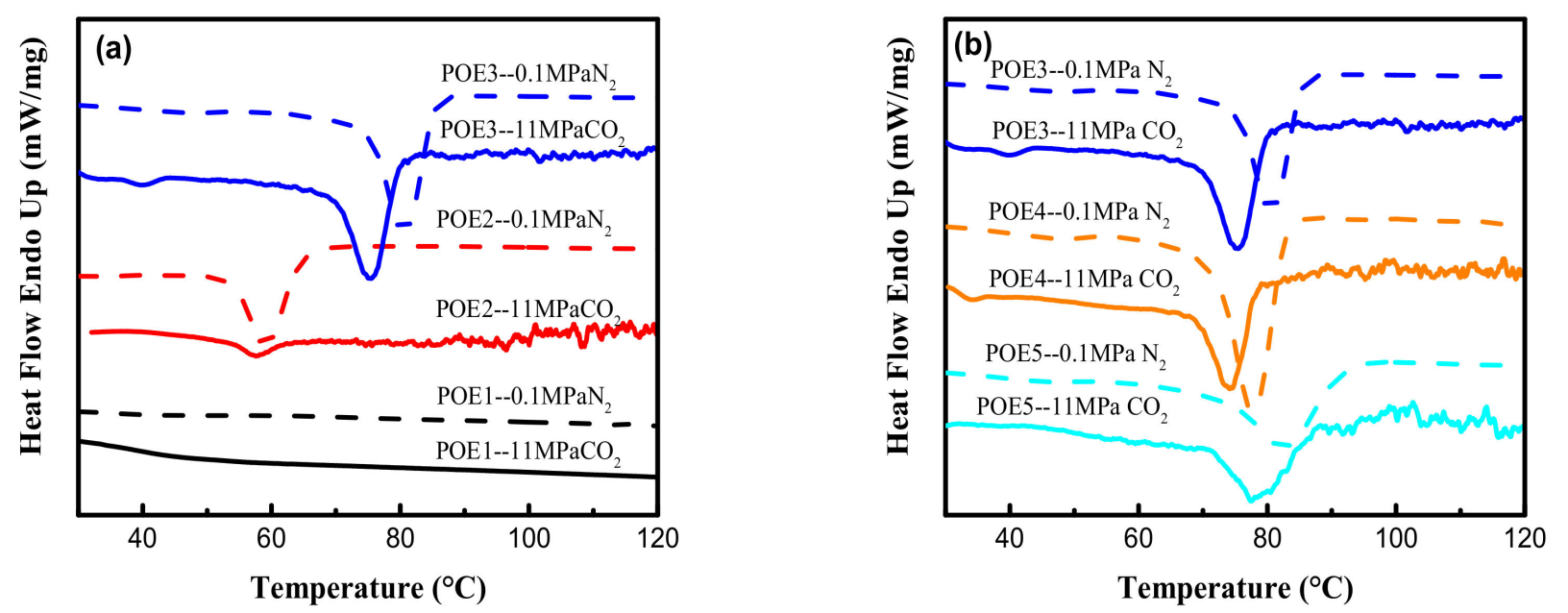

Figure 3. DSC curves of POE samples at a cooling rate of $10^{\circ} \mathrm{C} / \mathrm{min}$. (a) POE samples with same MI; (b) POE samples with same octene content.
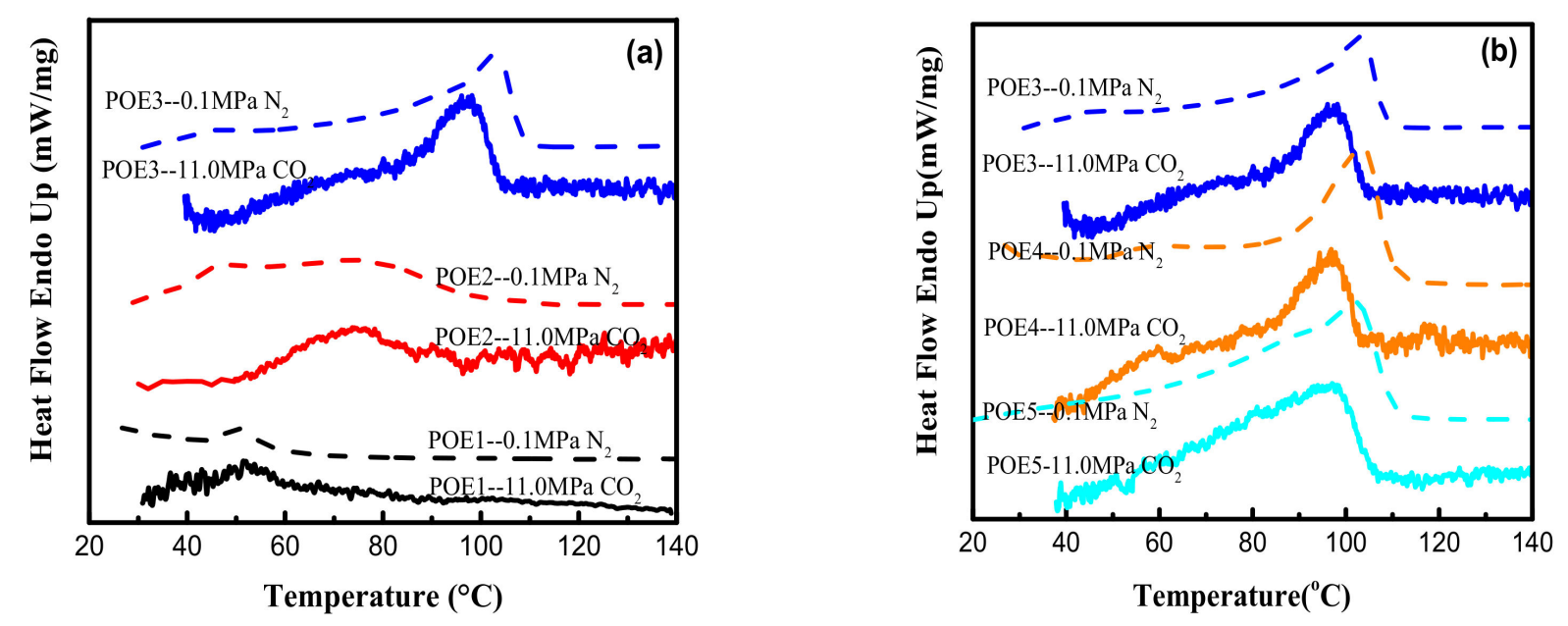

Figure 4. DSC curves of POE samples at a heating rate of $10^{\circ} \mathrm{C} / \mathrm{min}$. (a) POE samples with same MI; (b) POE samples with same octene content.

\subsection{Rheological Properties of POE}

The viscoelasticity is an important evaluation for polymer foamability. In order to explore the influence of temperature on the rheological properties of POE, the dynamic 
temperature scanning tests were carried out at a fixed frequency of $1 \mathrm{~Hz}$ and a controlled strain of $1.5 \%$ in the temperature range of $20-200{ }^{\circ} \mathrm{C}$ under a nitrogen atmosphere. As shown in Figure 6, in the solid state, the $\eta^{*}$ and $G^{\prime}$ of POE1-3 were obviously different, indicating that the octene content had a major effect on viscoelasticity. However, the $\eta^{*}$ and $G^{\prime}$ of POE3-5 were very close, implying that the molecular weight had little influence. In the complete melting stage, viscoelasticity was governed by molecular weight, which was consistent with the results of Zhai [8]. The shear thinning behaviors in the frequency range between $100 \mathrm{rad} / \mathrm{s}$ and $0.1 \mathrm{rad} / \mathrm{s}$ at $120^{\circ} \mathrm{C}$ were shown in Figure 7, which can be fitted by the cross model [27].

$$
\eta^{*}(\omega)=\frac{\eta_{0}}{1+(\lambda \omega)^{c}}
$$

where $\eta^{*}(\omega)$ is the complex viscosity, $\eta_{0}$ is the zero-shear viscosity, $\lambda$ is the characteristic relaxation time, $\omega$ is the angular frequency, and $c$ is the Cross index.

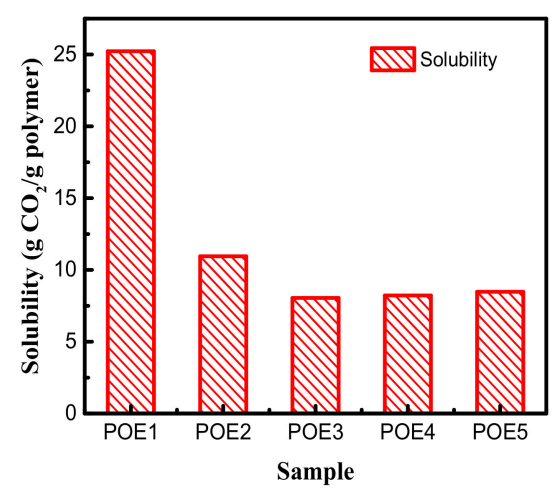

Figure 5. Solubility of $\mathrm{CO}_{2}$ in $\mathrm{POE}$ samples under $\mathrm{CO}_{2}$ pressure of $11 \mathrm{MPa}$ at $25^{\circ} \mathrm{C}$.
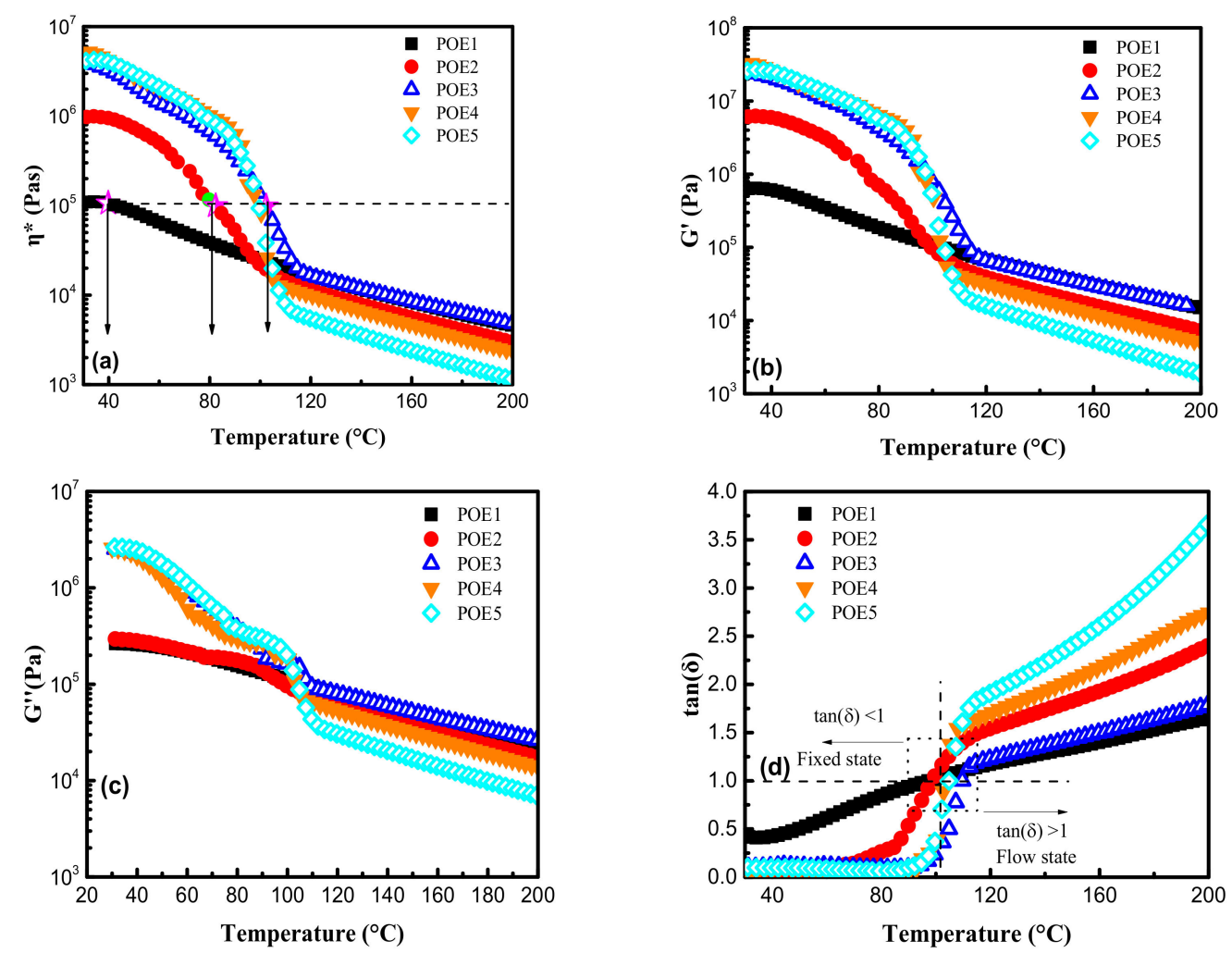

Figure 6. Temperature dependence of (a) complex viscosity, $\eta^{*}$; (b) storage modulus, $G^{\prime}$; (c) loss modulus, $G^{\prime \prime}$; (d) loss angle, $\tan (\delta)$ for POE samples during the temperature-rising sweep process. 

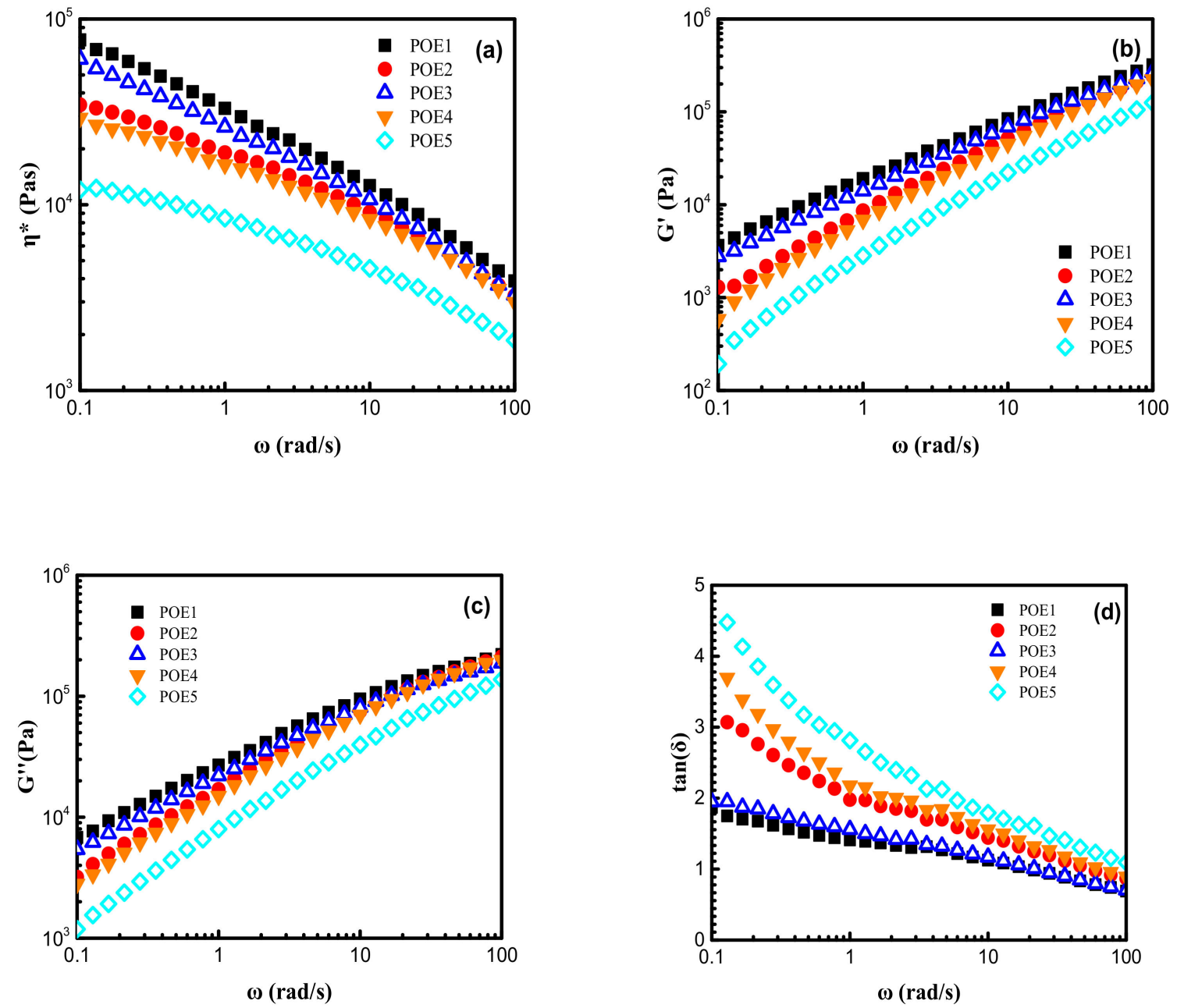

Figure 7. Shear rheological behaviors of POE samples measured at $120^{\circ} \mathrm{C}$ in the frequency range between $100 \mathrm{and} 0.1 \mathrm{rad} / \mathrm{s}$ : (a) complex viscosity, $\eta^{*}$; (b) storage modulus, $G^{\prime} ;(\mathbf{c})$ loss modulus, $G^{\prime \prime} ;(\mathbf{d})$ loss angle, $\tan (\delta)$.

When the nucleation and growth of bubbles occurred during the foaming process, the matrix was stretched. The elongational viscosity measurements were carried out to explore the biaxial stretching process of cell walls, and the Figure 8 displayed the elongational viscosity curves of five different POE samples, which all showed strain hardening behaviors, but POE1 with highest octene content exhibited obvious weakest strain hardening behaviors, due to the lowest long-chain branching content.

\subsection{Foaming Behaviors}

Figure 9 was SEM images and Figure 10 summarized the expansion ratio of different POE foams, which were totally stabilized at the aging time of 21 days. As mentioned above, the foaming temperature window of different POEs was close to their POE melting range. Figure 10a shows that the foaming window shifts to the lower temperature range with the increase of octene content. POE foams with lower octene content have a higher expansion ratio, which can be up to 18.9 times. Figure 10b shows that the increase of POE molecular weight can widen the foaming temperature window and increase the expansion ratio.

From Figure 9, it can be seen that the foam samples of POE with lower octene content exhibit better closed-cell structure. Table 4 shows that POEs with lower octene content have longer relaxation times, which is conducive to the formation of a stable cell structure. Chen et al. [28] found that a longer relaxation time was beneficial to the foamability of polymer. Li et al. [29] proved that longer relaxation time allows cells to grow steadily for a longer time. In addition, chain structure also has a great influence on cell growth. 
Jiang et al. [30,31] prepared highly branched TPEE elastomers and found that TPEE foam cells with more branched structures were more stable. The increase of branch content was conducive to the stability of the cell wall stretching during the bubble growth process [32]. Previous work $[33,34]$ proved that long-chain branching increased with decreased octene content. As shown in Tables 1,2 and 4, with lower molecular weight and lower octene content than POE1; POE3 showed longer characteristic relaxation time. Figure 8 showed that POEs with lower octene content had more significant strain hardening behaviors. Both the relaxation time and the elongational rheological properties indicated that the POE with lower octene content had more long chain branches. From Figure 11, it is found that POE with higher molecular weight has higher cell density and smaller cell size due to higher melt strength, shown in Figure 7. Similar to the foaming behaviors of other thermoplastic polymers, when the foaming temperature is higher than the melting point of the material, the cell density of different types of POE foams significantly decreases with the increase of temperature.
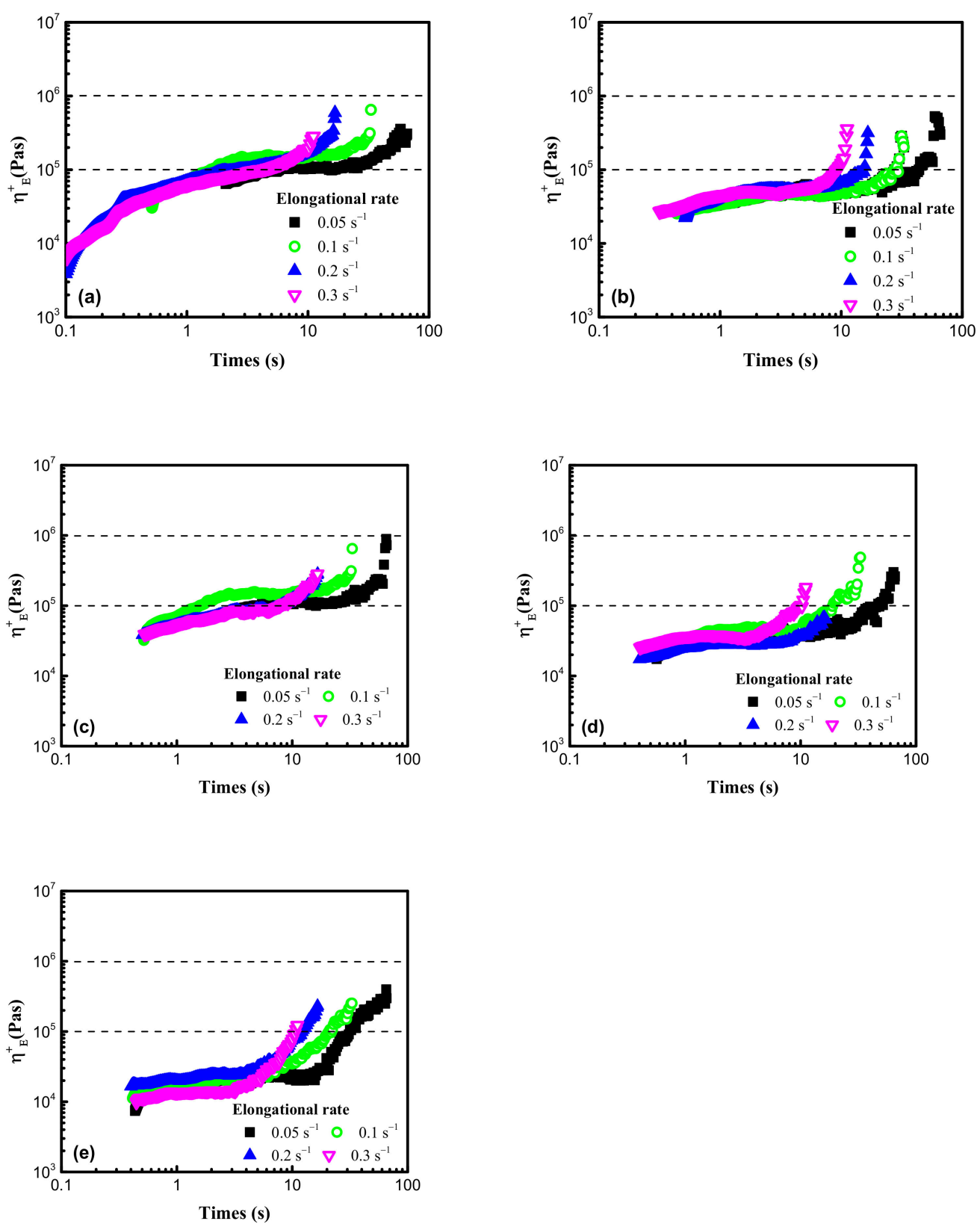

Figure 8. Elongational viscosities for 5 POE samples, at temperature of $150^{\circ} \mathrm{C}$. (a) POE1; (b) POE2; (c) POE3; (d) POE4; (e) POE5. 

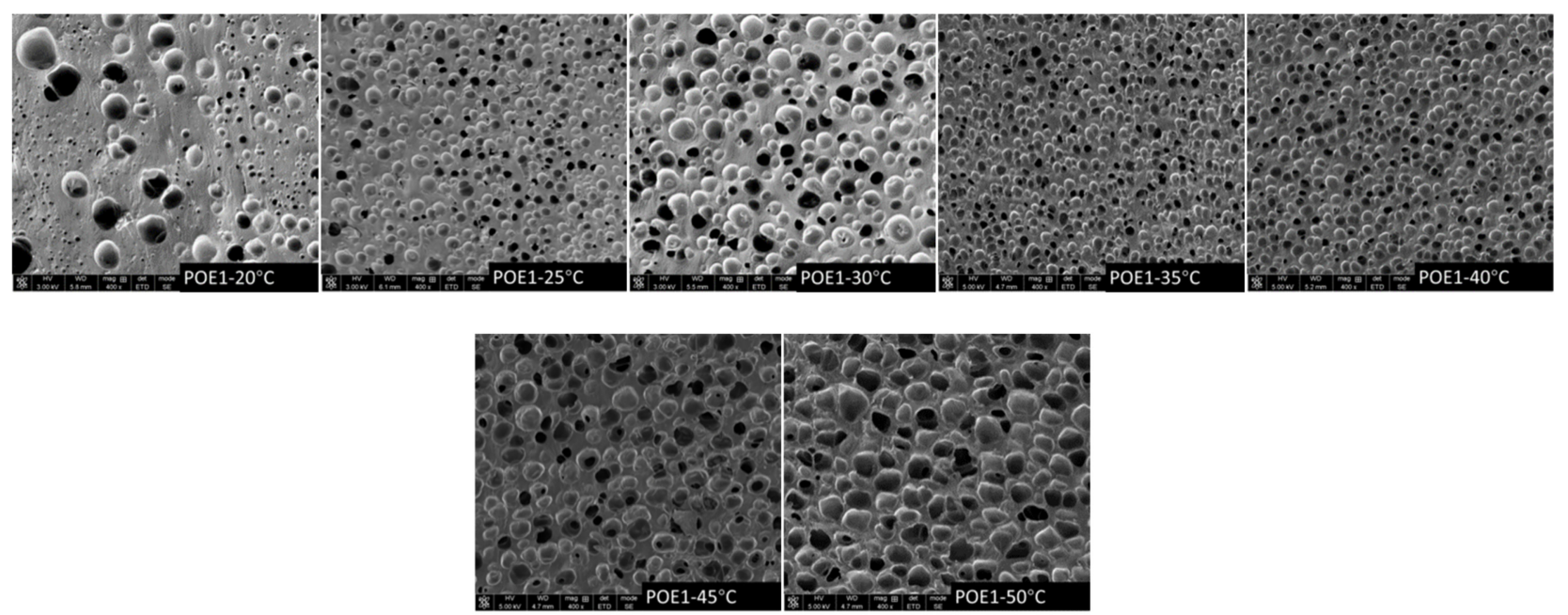

(a)
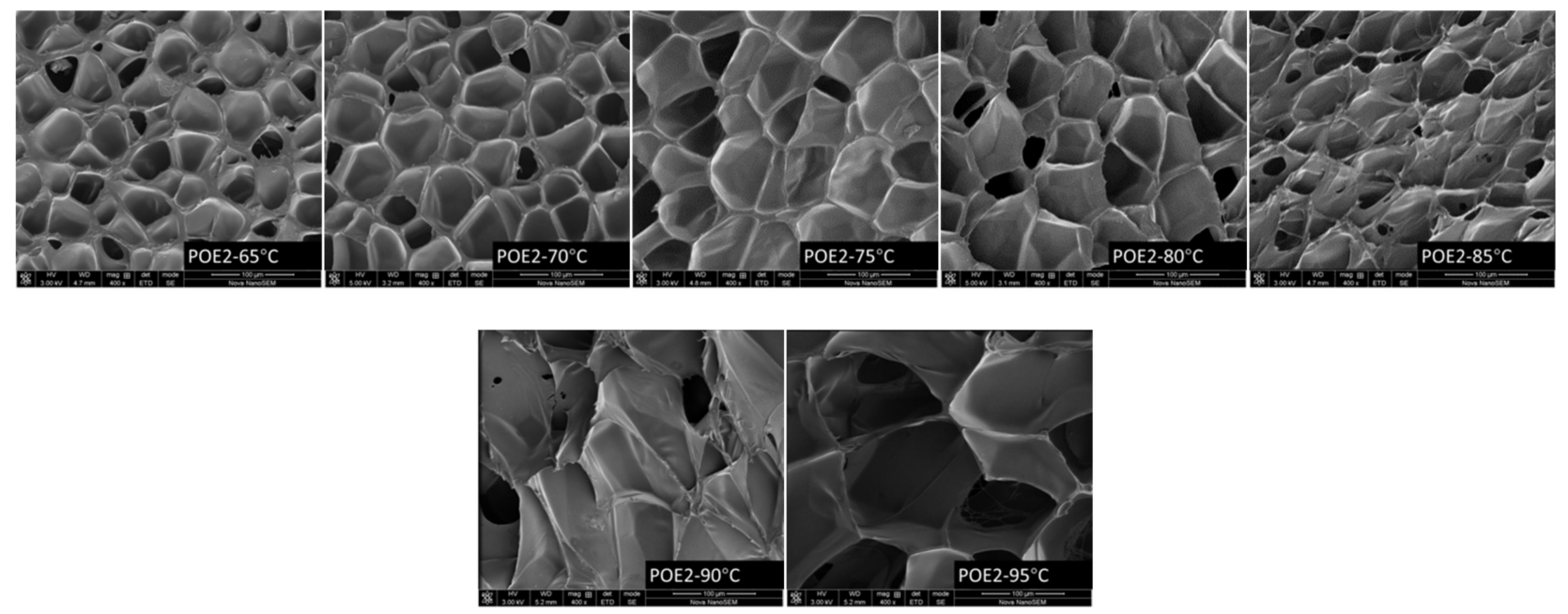

(b)
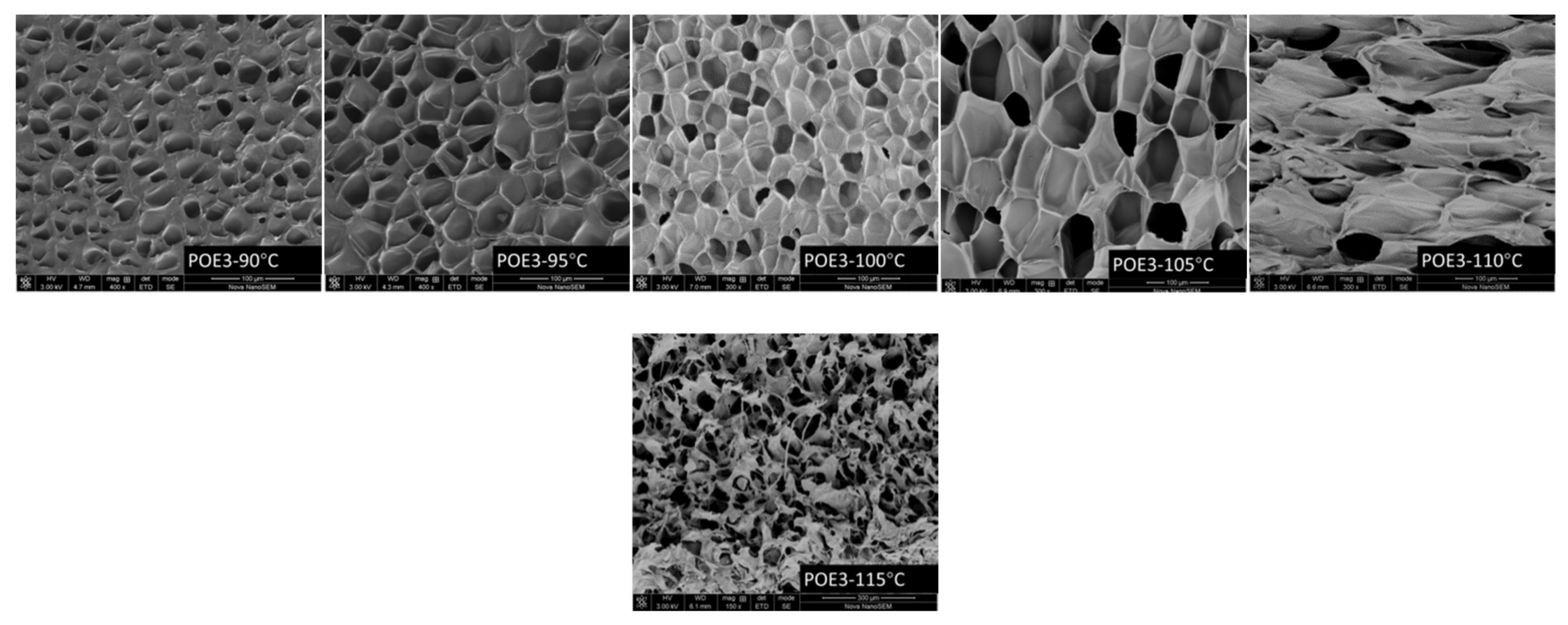

(c)

Figure 9. Cont. 

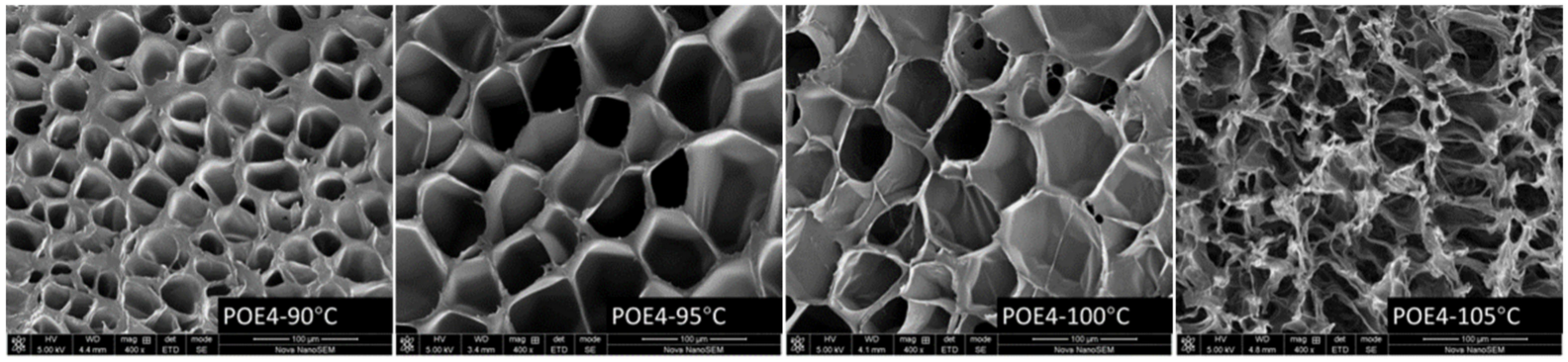

(d)
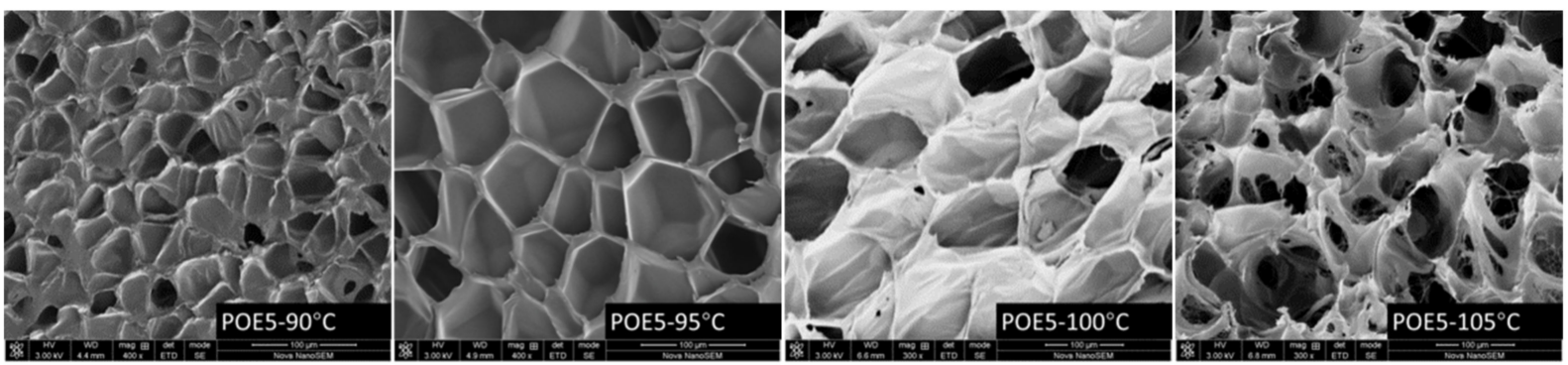

(e)

Figure 9. SEM micrographs of POE foams prepared at different temperatures. The SEM was captured after the sample had been annealed in air at room temperature for 21 days. (a) POE1; (b) POE2; (c) POE3; (d) POE4; (e) POE5.
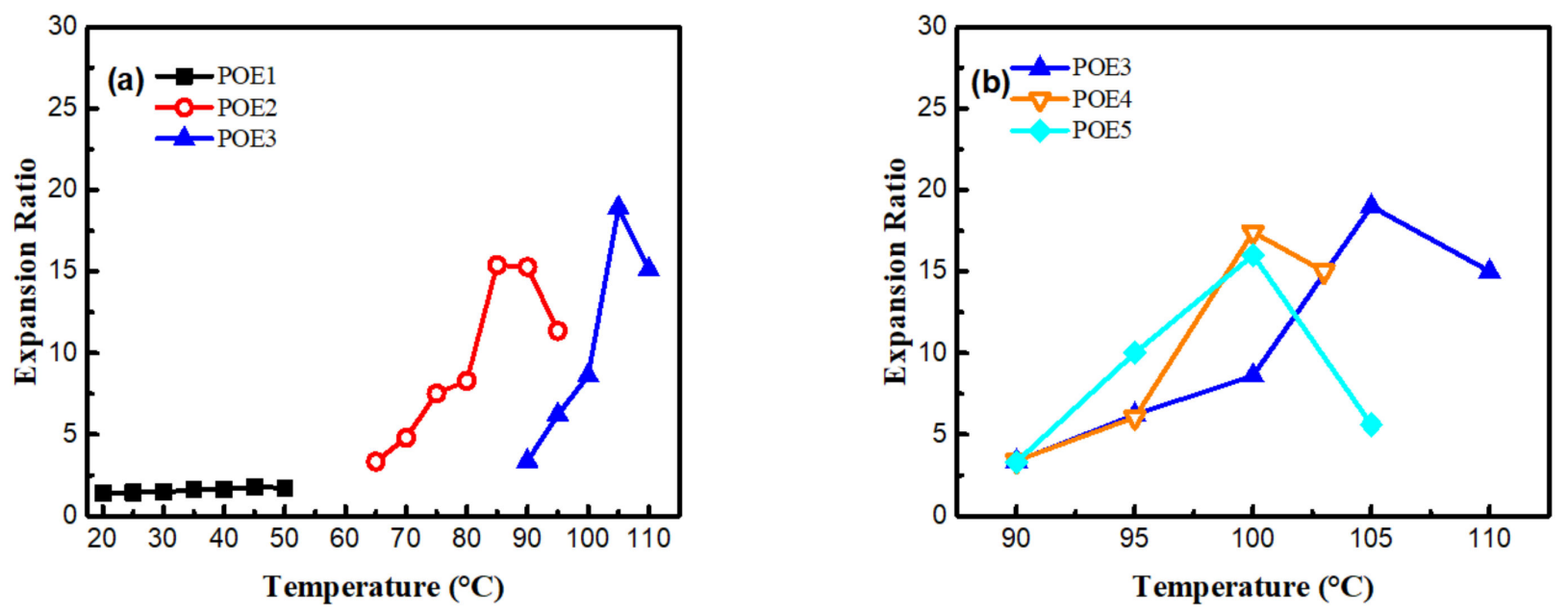

Figure 10. Expansion ratio of POE foams obtained at different temperature. The expansion ratio was measured at the aging time of 21 days. (a) POE samples with same MI; (b) POE samples with same octene content.

Table 4. Rheological parameters of POE with different chain structures.

\begin{tabular}{cccc}
\hline Sample & $c$ & $\lambda$ & $\eta_{\mathbf{0}}$ \\
\hline POE1 & 0.46 & 42.38 & $226,013.6$ \\
POE2 & 0.43 & 6.63 & $63,787.3$ \\
POE3 & 0.40 & 119.39 & $233,983.3$ \\
POE4 & 0.42 & 6.15 & $52,149.6$ \\
POE5 & 0.45 & 0.88 & $16,610.2$ \\
\hline
\end{tabular}



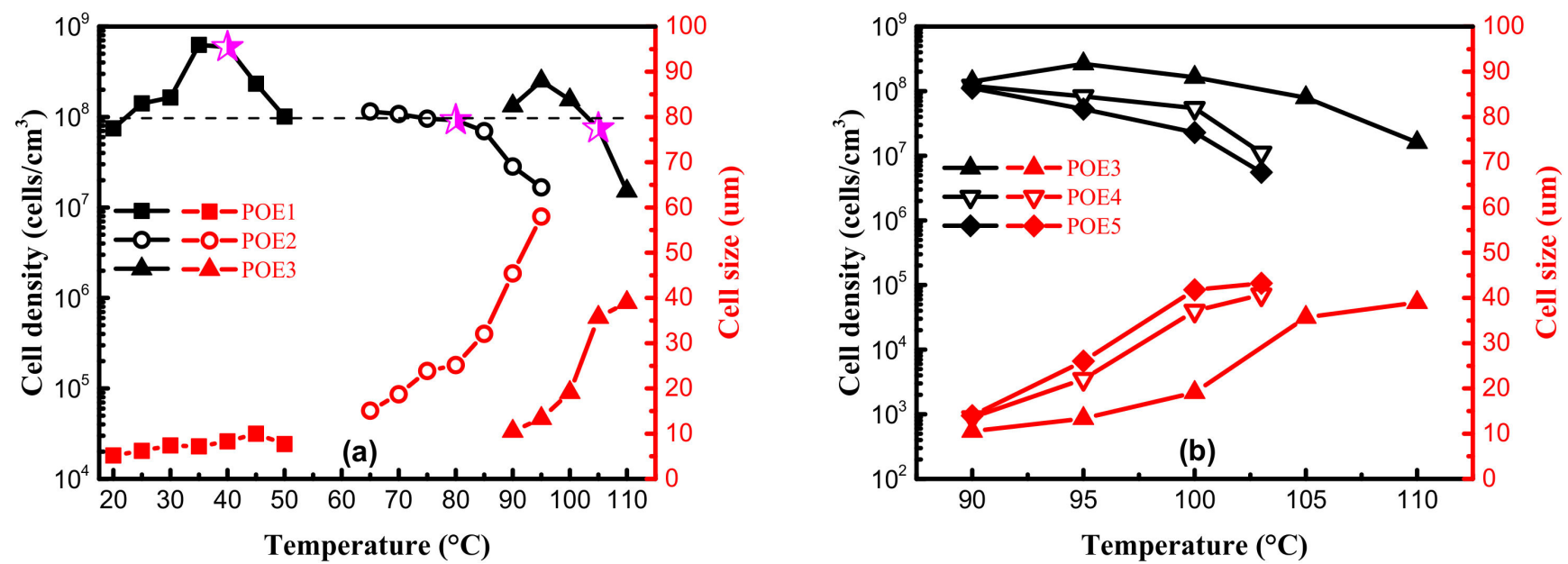

Figure 11. Cell density and cell size of POE foams obtained at different temperature. The data was measured at the aging time of 21 days. (a) POE samples with same MI; (b) POE samples with same octene content.

Figure 12 summarized the solubility of $\mathrm{CO}_{2}$ in different $\mathrm{POE}$ samples at foaming temperatures with a constant pressure of $11 \mathrm{MPa}$. POEs with higher octene content have higher solubility. In contrast, the molecular weight has a little effect on the solubilities for POEs with about $4.5 \%$ octene content; Zhai et al. [8] got a similar conclusion. It is generally believed that the dissolution and diffusion of gas in polymers only occurs in the amorphous phase, and the crystalline phase is a barrier to gas diffusion [35,36]. Li [37] proved that when the temperature was high enough and the polymer was completely molten, where there is no crystallization, solubility would decrease as the temperature increased. In order to explore the influence of octene content on cell density, the temperature conditions of POE1, POE2, and POE3 with the same $\eta^{*}$ were found in Figure $6 \mathrm{a}$, that is $40{ }^{\circ} \mathrm{C}, 80^{\circ} \mathrm{C}$, $105^{\circ} \mathrm{C}$, to eliminate the effect of the melt strength, it was found that POE with higher gas solubility (shown in Figure 12) had higher cell density (shown in Figure 11). According to classical nucleation theory [38,39], the increase of gas solubility can increase cell nucleation rate [40]. Therefore, the increase in octene content is beneficial to increase the cell density of POE foams.
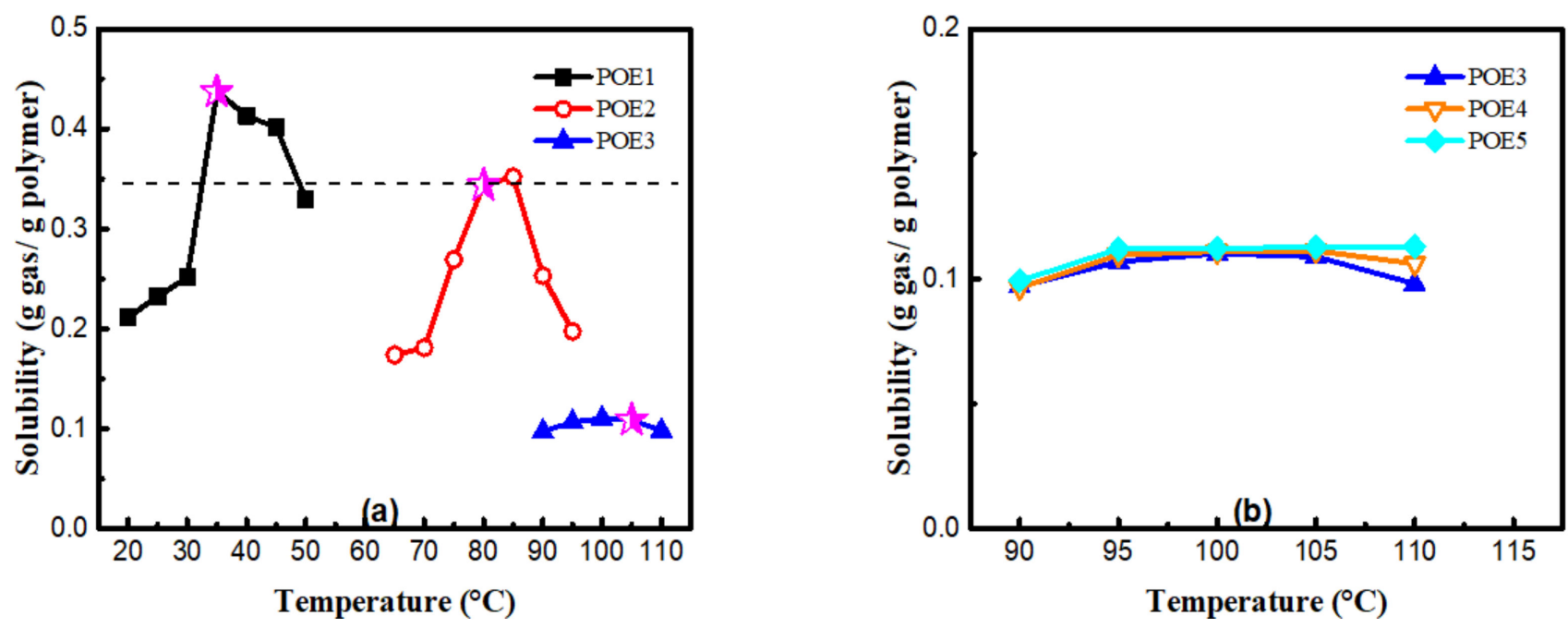

Figure 12. $\mathrm{CO}_{2}$ solubility in POEs measured at certain temperature. (a) POE samples with same MI; (b) POE samples with same octene content. 


\subsection{Dimensional Stability of POE Foams}

The shrinkage behaviors of polymer foams are mainly caused by two aspects: the difference in the diffusion between blowing agent and air; the mechanical strength of polymer matrix itself. Figure 13 showed the volume shrinkage ratio of all POE foams after 21 days of aging. With the decrease of octene content from $16.54 \%$ to $4.48 \%$, the volume shrinkage ratios of POE foams decrease from $52-75 \%$ to $17-6 \%$; while molecular weight has little effect on the shrinkage behavior. As shown in Figure 6, the increase in octene content reduces the slopes of $\eta^{*}$ and $G^{\prime}$ with temperature, indicating that the temperature has a weaker effect on the viscoelasticity of POE with higher octene content and the lower viscoelasticity and weaker temperature response caused by the increase of octene content are disadvantages for cell structure stabilization during the foaming process.
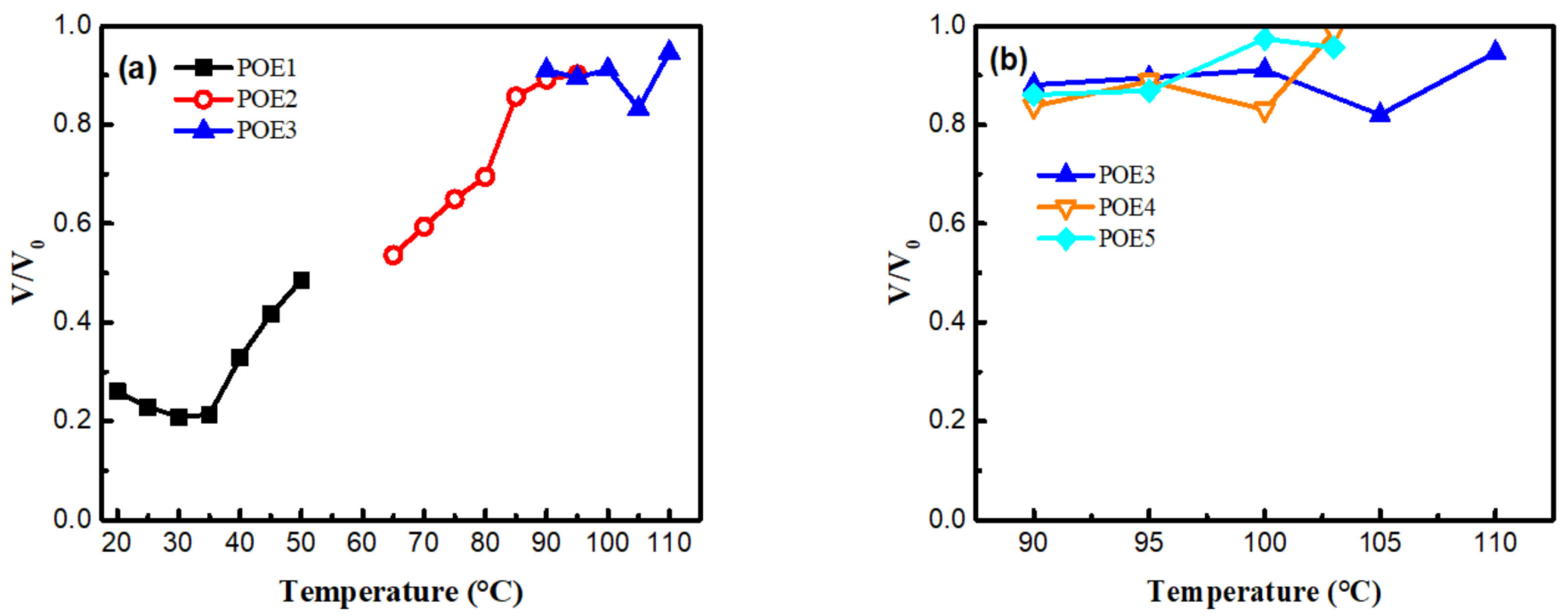

Figure 13. $\mathrm{V} / \mathrm{V}_{0}$ of POE foams obtained at different temperature. $\mathrm{V} / \mathrm{V}_{0}$ is the volume ratio after 21 days for aging and the first test at the time of $1 \mathrm{~min}$ (a) POE samples with same MI; (b) POE samples with same octene content.

Figure 14 summarized the shrinkage behaviors of POE foams with different chain structures over time. POE foams with higher octene content display more serious shrinkage behaviors. The decrease in molecular weight or the increase in octene content can increase the permeability of $\mathrm{CO}_{2}$. As shown in Table 5, the diffusion of $\mathrm{CO}_{2}$ in all POE samples was an order of magnitude larger than that of air, which provided the foam a driving force to shrink. Increasing octene content can increase the driving force for shrinkage. Then, the influence of chain structures on the mechanical behavior of the POEs was investigated. The strain rate was controlled at $1 \mathrm{~mm} / \mathrm{min}$, and the change in stress with strain was recorded in Figure 15. POE samples with higher octene content and lower molecular weight show lower compression modulus due to the difference in crystallinity and crystal structure. The cell structures of POE foams with lower modulus have poor resistance to negative pressure and are more prone to shrinkage and deformation.

Table 5. Some parameters for dimensional stability of POE foams.

\begin{tabular}{cccc}
\hline Sample Number & Pe $_{\text {air }} \mathbf{~} \mathbf{k g}$ gas/(m·s·MPa) & Pe $_{\mathbf{C O} 2} \mathbf{( k g}$ gas/(m·s·MPa) & Compression Modulus $(\mathbf{M P a})$ \\
\hline POE1 & $4.66 \times 10^{-10}$ & $2.43 \times 10^{-8}$ & 9.67 \\
POE2 & $4.49 \times 10^{-10}$ & $4.92 \times 10^{-9}$ & 22.95 \\
POE3 & $4.20 \times 10^{-10}$ & $2.83 \times 10^{-9}$ & 38.78 \\
POE4 & $4.60 \times 10^{-10}$ & $3.23 \times 10^{-9}$ & 36.54 \\
POE5 & $4.72 \times 10^{-10}$ & $3.44 \times 10^{-9}$ & 34.55 \\
\hline
\end{tabular}



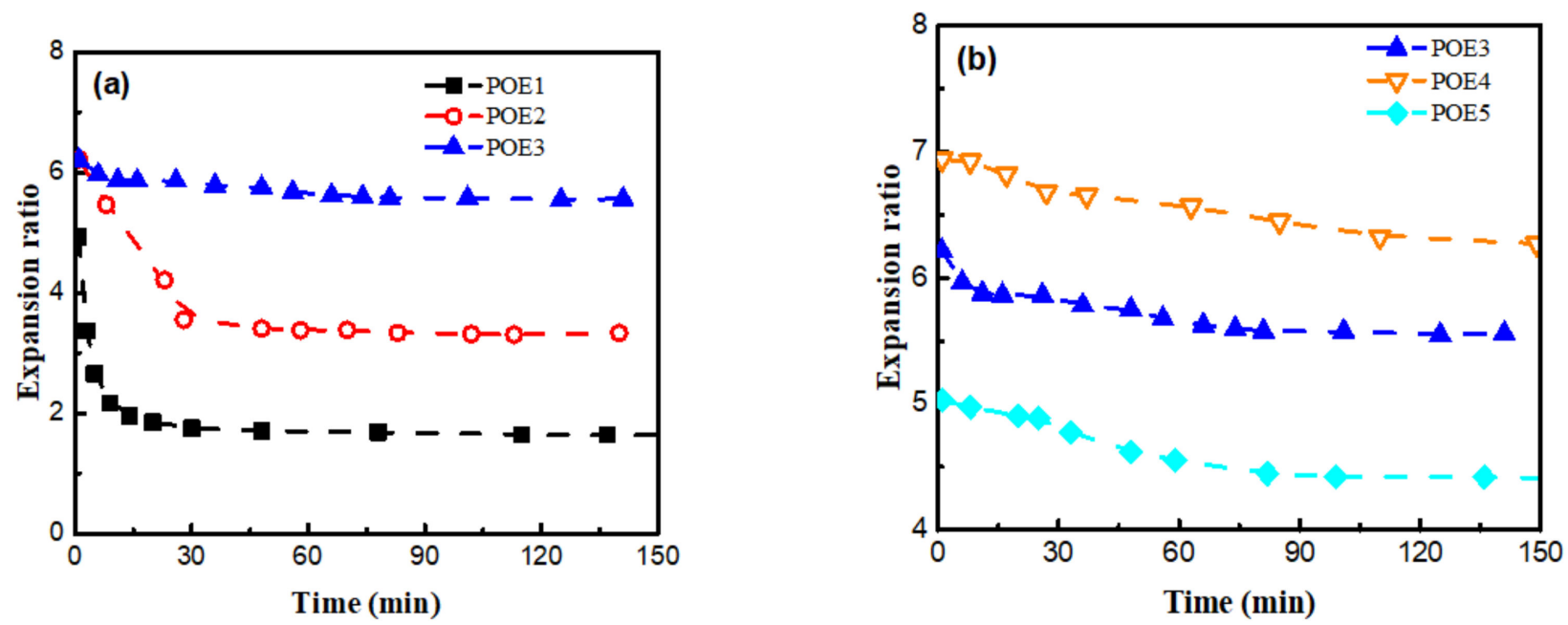

Figure 14. Shrinkage behavior of POE foams with lower expansion ratio. (a) POE samples with same MI; (b) POE samples with same octene content.

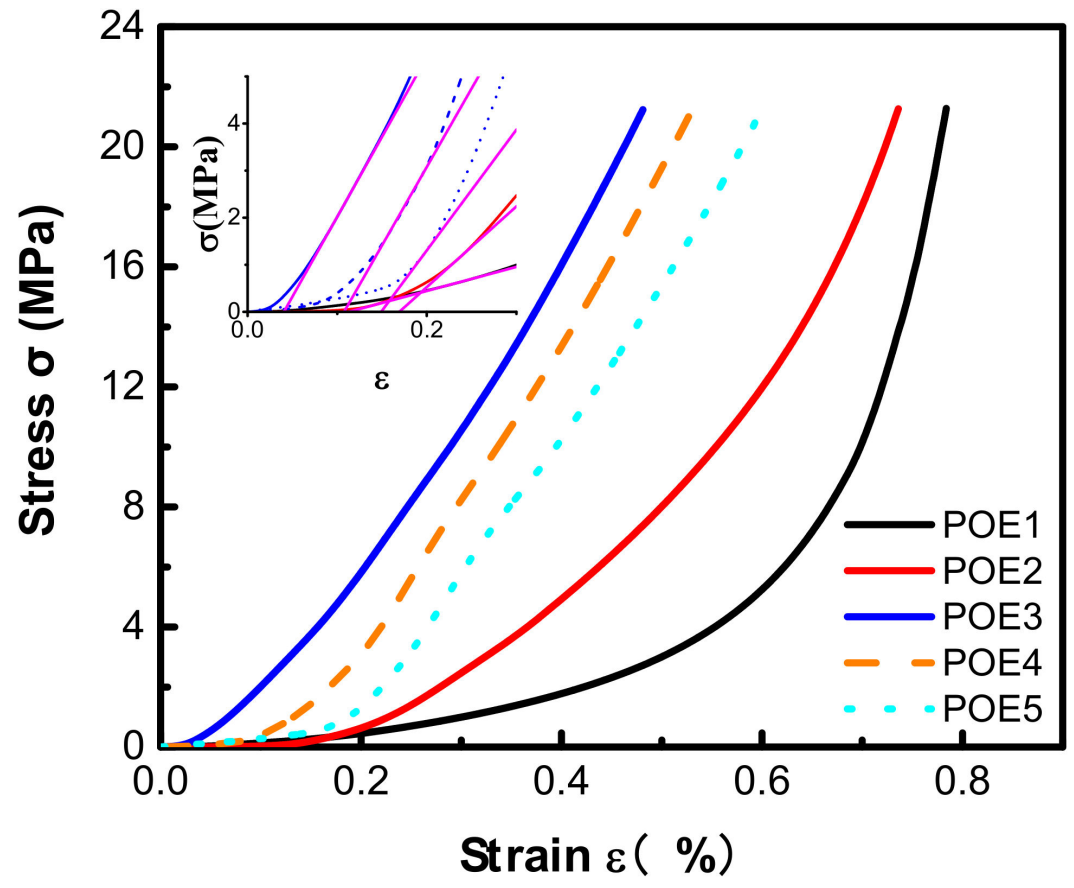

Figure 15. Compressive stress-strain curves of different POEs.

However, when the initial expansion ratio of POE foams is high enough, there are more serious foam shrinkage and more obvious shrinkage recovery phenomenon except POE1, as shown in Figure 16. The shrinkage recovery behavior is mainly controlled by the viscoelastic recovery of the cell wall [41]. The shrinkage recovery of polymer foam is also the process of the creep recovery process of cell wall. The elastic properties of POE cell wall are controlled by its crystalline structure [42]. POE samples (POE2-5) with $2 \theta=21.4^{\circ}$, $23.5^{\circ}$, and $36.1^{\circ}$ peaks have stronger multifunctional junctions [11], which is beneficial to the stability of cell walls. In order to further explore the shrinkage recovery behavior of cell wall, POE samples compression creep recovery experiments were conducted. A stress level of $0.75 \mathrm{MPa}$ was employed to POE solid samples with a loading time of $1 \mathrm{~h}$. Figure 17 showed the strain of all samples as a function of time. Similar to un-vulcanized rubber, POE1 with higher octene content and weaker crystalline structure had a lower modulus and greater permanent deformation, when being compressed. Therefore, POE1 foams hardly recovered after shrinking in the full foaming temperature window. As the octene content 
decreases, POE2-5 had good creep recovery behaviors, due to stronger crystalline structure, and their foams samples showed obvious shrinkage recovery behavior. All POE foams couldn't have fully recovered after shrinking, due to the permanent deformation caused by the separation of the polymer chain from the surface of the crystal and reconnection to a neighboring crystal [42].
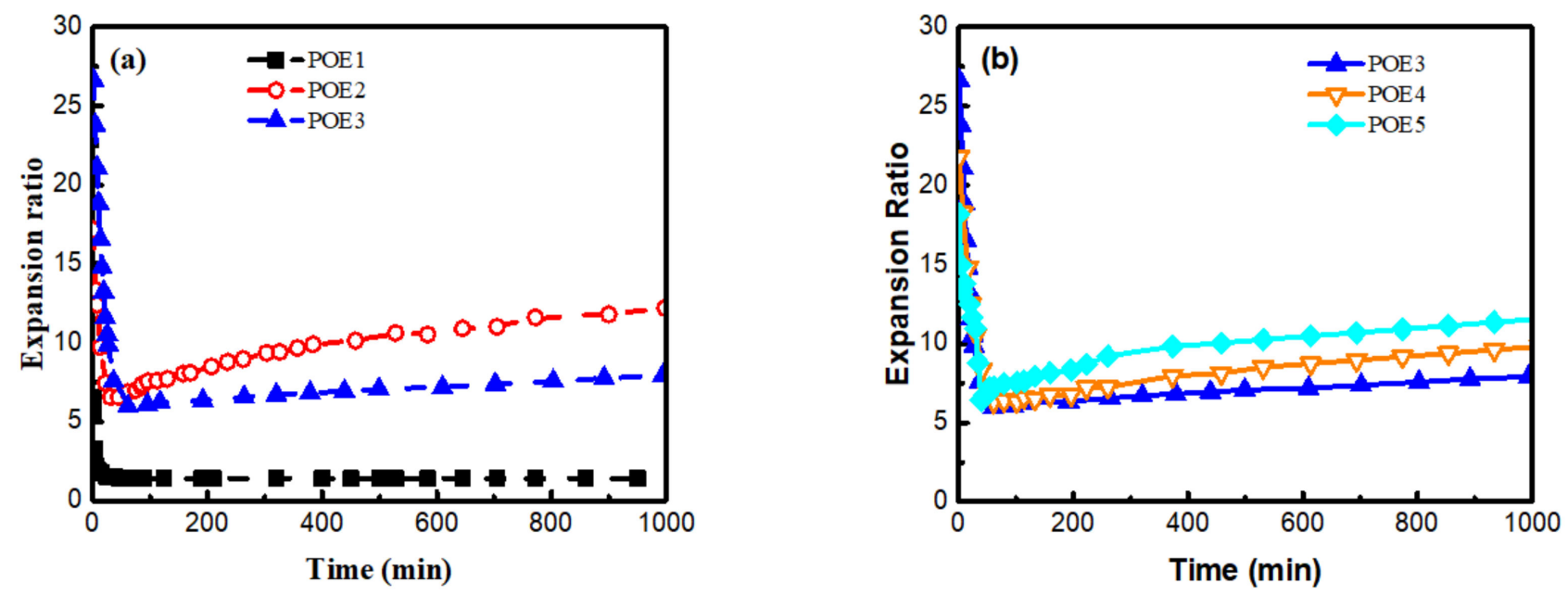

Figure 16. Shrinkage recovery behavior of POE foams with higher expansion ratio. (a) POE samples with same MI; (b) POE samples with same octene content.

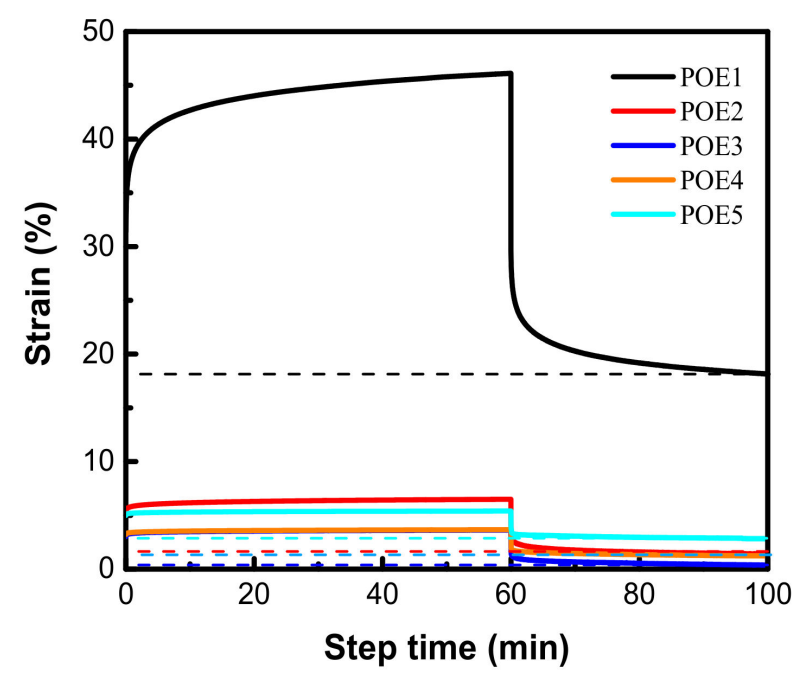

Figure 17. Creep curves of different POE solid samples at $40^{\circ} \mathrm{C}$ and $0.75 \mathrm{MPa}$.

The differences in shrinkage behaviors between high expansion ratio (over 17 times) foams and low expansion ratio foams are mainly caused by the difference in cell structure. Figure 18 showed initial cell length and cell wall thickness. The cell wall parameters corresponding to the foams in Figure 16 were marked with magenta five-pointed stars. POE foams with a higher expansion ratio have a thinner cell wall thickness and a larger cell length. A shorter and thicker cell wall structure can be found for POE1 foams in Figure 18a, which causes more compression deformation of cell wall. Through the comparison of foam samples of POE3-5 with similar mechanical properties, the longer cell wall structure makes the foam shrinkage recover faster in the condition of similar cell wall thickness. It was found by SEM that the cell shape was roughly circular or hexagonal. Therefore, when the foam is compressed, the force on cell wall has two effects: axial compressive force, which causes the cell wall to undergo compression deformation, and the vertical axial force that causes the cell wall to bend. According to generalized beam theory [43], longer and thinner 
cell walls are easier to bend. The polymer needs to be stretched to recover to its original length after compression deformation, while the bending deformation can be recovered under ideal conditions when the pressure disappears. The shrinkage recovery behaviors of foams with thinner cell wall and longer cell length are better, because more bending deformation occurs instead of compression deformation, thereby reducing permanent deformation, due to chain slippage.
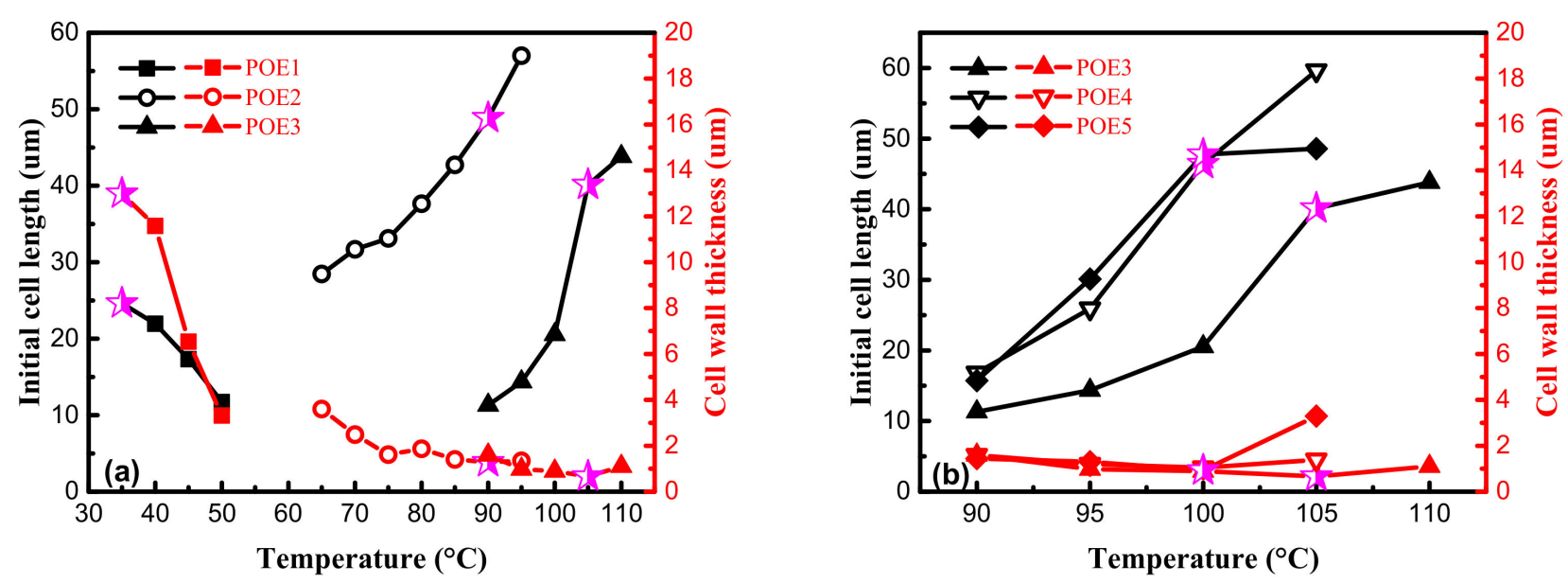

Figure 18. Effect of saturation temperature on initial cell length and cell wall thickness. (a) POE samples with same MI; (b) POE samples with same octene content.

\section{Conclusions}

POE foams with different compositions and molecular weights were prepared with cell density range from $6.6 \times 10^{6}$ to $6.2 \times 10^{8}$ and average cell diameter from 4.3 to $57.9 \mathrm{um}$ using supercritical $\mathrm{CO}_{2}$ as a blowing agent. Combined their crystallization and melting behaviors, gas dissolution and diffusion, rheology properties, it is found that higher octene content as well as $\mathrm{CO}_{2}$ plasticization could significantly reduce the melting temperature of POEs and make the foaming window move to lower temperature range. The increase of octene content significantly increases the solubility and desorption rate of $\mathrm{CO}_{2}$ in $\mathrm{POE}$, due to less ethylene homo-polymerization crystalline segment content, thereby increasing the cell density of POE; while POE foams with higher molecular weight have higher cell density and wider foaming window because of higher melt strength to inhibit cell coalescence and rupture. The shrinkage behavior of POE foams is further analyzed based on their mechanical properties and structure of cell wall. Firstly, the increase in octene content can reduce POE crystallinity and change the crystal form from lamellar to bundled crystals, which makes the compression creep recovery of cell wall worse. POE foam with higher octene content shrinks more severely. When the octene content reach $16.54 \%$ and the triad sequence length distribution of EEE is reduced to $60.9 \%$, the lamellar crystals disappear completely, and there is a serious shrinkage and almost no recovery in POE1 foams during aging process. Since molecular weight shows little effect on mechanical properties and $\mathrm{CO}_{2}$ diffusion behavior, the shrinkage behavior of $\mathrm{POE}$ foams with different molecular weights is similar. Secondly, higher expanded POE foam with longer and thinner cell wall structure has a more serious shrinkage problem, but its shrinkage recovery behavior is also more obvious, due to easily occurring of bending deformation, rather than compression deformation.

Author Contributions: Conceptualization, L.Z. and D.H.; software, D.L.; validation, L.Z. and D.H.; formal analysis, Y.C. and H.Z.; investigation, D.L.; resources, L.Z.; data curation, D.L.; WritingOriginal Draft preparation, D.L.; Writing-Review and Editing, L.Z. and Y.C.; visualization, S.Y.; supervision, L.Z.; project administration, L.Z.; funding acquisition, L.Z. All authors have read and agreed to the published version of the manuscript. 
Funding: This research was funded by the National Key Research and Development Program of China (2016YFB0302200) and the Fundamental Research Funds for the Central Universities.

Institutional Review Board Statement: Not applicable.

Informed Consent Statement: Not applicable.

Data Availability Statement: The data presented in this study are available on request from the corresponding author.

Conflicts of Interest: The authors declare no conflict of interest.

\section{References}

1. Acevedo, M.E.; Quijada, R.; Vallette, M.C. Thermal oxidation of metallocene ethylene-1-olefin copolymer films during one year oven aging. Polym. Degrad. Stab. 2008, 93, 1947-1951. [CrossRef]

2. Li, T.; Ma, L.-F.; Bao, R.-Y.; Qi, G.-Q.; Yang, W.; Xie, B.-H.; Yang, M.-B. A new approach to construct segregated structures in thermoplastic polyolefin elastomers towards improved conductive and mechanical properties. J. Mater. Chem. A 2015, 3 , 5482-5490. [CrossRef]

3. Liu, Z.; Chen, S.; Zhang, J. Photodegradation of ethylene-octene copolymers with different octene contents. Polym. Degrad. Stab. 2011, 96, 1961-1972. [CrossRef]

4. Zhao, T.; Yang, M.; Wu, H.; Guo, S.; Sun, X.; Liang, W. Erratum to "Preparation of a new foam/film structure poly(ethyleneco-octene) foam materials and its sound absorption properties" [Mater. Lett. 139 (2014) 275-278]. Mater. Lett. 2015, 145, 363. [CrossRef]

5. Nayak, N.C.; Tripathy, D.K. Morphology and physical properties of closed cell microcellular ethylene-octene copolymer: Effect of precipitated silica filler and blowing agent. J. Appl. Polym. Sci. 2002, 83, 357-366. [CrossRef]

6. Tatibouet, J.; Gendron, R.; Haider, L. Ultrasonic characterization performed during chemical foaming of cross-linked polyolefins. Polym. Test. 2004, 23, 125-130. [CrossRef]

7. Gendron, R.; Vachon, C. Effect of viscosity on low density foaming of poly(ethylene-co-octene) resins. J. Cell. Plast. 2003, 39, 71-85. [CrossRef]

8. Zhai, W.; Leung, S.N.; Wang, L.; Naguib, H.E.; Park, C.B. Preparation of Microcellular Poly(ethylene-co-octene) Rubber Foam with Supercritical Carbon Dioxide. J. Appl. Polym. Sci. 2010, 116, 1994-2004. [CrossRef]

9. Zhai, W.; Wang, J.; Chen, N.; Naguib, H.E.; Park, C.B. The orientation of carbon nanotubes in poly(ethylene-co-octene) microcellular foaming and its suppression effect on cell coalescence. Polym. Eng. Sci. 2012, 52, 2078-2089. [CrossRef]

10. Bensason, S.; Minick, J.; Moet, A.; Chum, S.; Hiltner, A.; Baer, E. Classification of homogeneous ethylene-octene copolymers based on comonomer content. J. Polym. Sci. Part B Polym. Phys. 1996, 34, 1301-1315. [CrossRef]

11. Perez, E.; Benavente, R.; Quijada, R.; Narvaez, A.; Galland, G.B. Structure characterization of copolymers of ethylene and 1-octadecene. J. Polym. Sci. Part B Polym. Phys. 2000, 38, 1440-1448. [CrossRef]

12. Yeh, S.-K.; Chen, Y.-R.; Kang, T.-W.; Tseng, T.-J.; Peng, S.-P.; Chu, C.-C.; Rwei, S.-P.; Guo, W.-J. Different approaches for creating nanocellular TPU foams by supercritical $\mathrm{CO}_{2}$ foaming. J. Polym. Res. 2017, 25. [CrossRef]

13. Jiang, R.; Hu, D.; Liu, T.; Zhao, L. Influence of hard segment content of thermoplastic polyetherester elastomer on its supercritical $\mathrm{CO}_{2}$ foaming behavior. CIESC J. 2020, 71, 871-878. [CrossRef]

14. Zhai, W.; Jiang, J.; Park, C.B. A review on physical foaming of thermoplastic and vulcanized elastomers. Polym. Rev. 2021, 1-47. [CrossRef]

15. Zhang, X.H.; Zhai, W.T. Coloured TPU Foam Material, Preparation Methodand Use Thereof, as well as Method for Preparing Shaped Body, Sheet and Shoe Material by Using Same. U.S. Patent 10,035,894, 31 July 2018.

16. Jiang, X.; Zhao, L.; Feng, L.; Chen, C. Microcellular thermoplastic polyurethanes and their flexible properties prepared by mold foaming process with supercritical $\mathrm{CO}_{2}$. J. Cell. Plast. 2019, 55, 615-631. [CrossRef]

17. Lan, B.; Li, P.; Yang, Q.; Gong, P. Dynamic self generation of hydrogen bonding and relaxation of polymer chain segment in stabilizing thermoplastic polyurethane microcellular foams. Mater. Today Commun. 2020, 24, 101056. [CrossRef]

18. Zhang, R.; Huang, K.; Hu, S.; Liu, Q.; Zhao, X.; Liu, Y. Improved cell morphology and reduced shrinkage ratio of ETPU beads by reactive blending. Polym. Test. 2017, 63, 38-46. [CrossRef]

19. Zhang, H.; Fang, Z.; Liu, T.; Li, B.; Li, H.; Cao, Z.; Jin, G.; Zhao, L.; Xin, Z. Dimensional Stability of LDPE Foams with CO + i-C4H10 Mixtures as Blowing Agent: Experimental and Numerical Simulation. Ind. Eng. Chem. Res. 2019, 58, 13154-13162. [CrossRef]

20. Zhang, H.; Liu, T.; Li, B.; Li, H.; Cao, Z.; Jin, G.; Zhao, L.; Xin, Z. Anti-shrinking foaming of polyethylene with $\mathrm{CO}_{2}$ as blowing agent. J. Supercrit. Fluids 2020, 163, 104883. [CrossRef]

21. Zhang, H.; Liu, T.; Li, B.; Li, H.; Cao, Z.H.; Jin, G.; Zhao, L.; Xin, Z. Foaming and dimensional stability of LDPE foams with N-2, $\mathrm{CO}_{2}$, i-C4H10 and $\mathrm{CO}_{2}-\mathrm{N}-2$ mixtures as blowing agents. J. Supercrit. Fluids 2020, 164, 11. [CrossRef]

22. Azimi, H.R.; Rezaei, M. Solubility and diffusivity of carbon dioxide in St-MMA copolymers. J. Chem. Thermodyn. 2013, 58, 279-287. [CrossRef] 
23. Martinez, A.B.; Realinho, V.; Antunes, M.; Ll Maspoch, M.; Velasco, J.I. Microcellular Foaming of Layered Double HydroxidePolymer Nanocomposites. Ind. Eng. Chem. Res. 2011, 50, 5239-5247. [CrossRef]

24. ASTM. ASTM D5017-96(2009) e1 Determination of Linear Low Density Polyethylene (LLDPE) Composition by Carbon-13 Nuclear Magnetic Resonance; ASTM: West Conshohocken, PA, USA, 2009.

25. Russell, K.E.; McFaddin, D.C.; Hunter, B.K.; Heyding, R.D. Crystallization of side chains in copolymers of ethylene and 1-alkenes. J. Polym. Sci. Part B Polym. Phys. 1996, 34, 2447-2458. [CrossRef]

26. Wan, C.; Lu, Y.; Liu, T.; Zhao, L.; Yuan, W. Foaming of Low Density Polyethylene with Carbon Dioxide Based on Its in Situ Crystallization Behavior Characterized by High-Pressure Rheometer. Ind. Eng. Chem. Res. 2017, 56, 10702-10710. [CrossRef]

27. Wan, C.; Sun, G.; Liu, T.; Esseghir, M.; Zhao, L.; Yuan, W. Rheological properties of HDPE and LDPE at the low-frequency range under supercritical $\mathrm{CO}_{2}$. J. Supercrit. Fluids 2017, 123, 67-75. [CrossRef]

28. Chen, Y.; Wan, C.; Liu, T.; Chen, Z.; Qiao, Y.; Lu, J.; Yan, J.; Zhao, L.; Esseghir, M. Evaluation of LLDPE/LDPE blend foamability by in situ rheological measurements and bubble growth simulations. Chem. Eng. Sci. 2018, 192, 488-498. [CrossRef]

29. Li, Y.; Yao, Z.; Chen, Z.-h.; Cao, K.; Qiu, S.-1.; Zhu, F.-j.; Zeng, C.; Huang, Z.-m. Numerical simulation of polypropylene foaming process assisted by carbon dioxide: Bubble growth dynamics and stability. Chem. Eng. Sci. 2011, 66, 3656-3665. [CrossRef]

30. Jiang, R.; Chen, Y.; Yao, S.; Liu, T.; Xu, Z.; Park, C.B.; Zhao, L. Preparation and characterization of high melt strength thermoplastic polyester elastomer with different topological structure using a two-step functional group reaction. Polymer 2019, $179,121628$. [CrossRef]

31. Jiang, R.; Yao, S.; Chen, Y.; Liu, T.; Xu, Z.; Park, C.B.; Zhao, L. Effect of chain topological structure on the crystallization, rheological behavior and foamability of TPEE using supercritical $\mathrm{CO}_{2}$ as a blowing agent. J. Supercrit. Fluids 2019, 147, 48-58. [CrossRef]

32. Ge, Y.; Yao, S.; Xu, M.; Gao, L.; Fang, Z.; Zhao, L.; Liu, T. Improvement of Poly(ethylene terephthalate) Melt-Foamability by Long-Chain Branching with the Combination of Pyromellitic Dianhydride and Triglycidyl Isocyanurate. Ind. Eng. Chem. Res. 2019, 58, 3666-3678. [CrossRef]

33. Fetters, L.J.; Lohse, D.J.; Garcia-Franco, C.A.; Brant, P.; Richter, D. Prediction of melt state poly(alpha-olefin) rheological properties: The unsuspected role of the average molecular weight per backbone bond. Macromolecules 2002, 35, 10096-10101. [CrossRef]

34. Patham, B.; Jayaraman, K. Creep recovery of random ethylene-octene copolymer melts with varying comonomer content. J. Rheol. 2005, 49, 989-999. [CrossRef]

35. Ciora, R.J.; Magill, J.H. Novel rolltruded films. 4. Gas separation characteristics of rolltruded isotactic polypropylene. Polymer 1994, 35, 949-955. [CrossRef]

36. Puleo, A.C.; Paul, D.R.; Wong, P.K. Gas sorption and transport in semicrystalline poly(4-methyl-1-pentene). Polymer 1989, 30, 1357-1366. [CrossRef]

37. Li, G.; Gunkel, F.; Wang, J.; Park, C.B.; Altstaedt, V. Solubility measurements of N-2 and $\mathrm{CO}_{2}$ in polypropylene and ethene/octene copolymer. J. Appl. Polym. Sci. 2007, 103, 2945-2953. [CrossRef]

38. Kim, Y.; Park, C.B.; Chen, P.; Thompson, R.B. Origins of the failure of classical nucleation theory for nanocellular polymer foams. Soft Matter 2011, 7, 7351-7358. [CrossRef]

39. Oxtoby, D.W. Nucleation of First-Order Phase Transitions. Acc. Chem. Res. 1998, 31, 91-97. [CrossRef]

40. Kusaka, I.; Talreja, M.; Tomasko, D.L. Beyond classical theory: Predicting the free energy barrier of bubble nucleation in polymer foaming. AIChE J. 2013, 59, 3042-3053. [CrossRef]

41. Rodriguez-Perez, M.A.; Diez-Gutierrez, S.; De Saja, J.A. The recovery behavior of crosslinked closed cell polyolefin foams. Polym. Eng. Sci. 1998, 38, 831-837. [CrossRef]

42. Bensason, S.; Stepanov, E.V.; Chum, S.; Hiltner, A.; Baer, E. Deformation of elastomeric ethylene-octene copolymers. Macromolecules 1997, 30, 2436-2444. [CrossRef]

43. Schardt, R. Generalized beam theory-an adequate method for coupled stability problems. Thin Walled Struct. 1994, 19, 161-180. [CrossRef] 